\title{
SEASONAL SCARCITY AND SHARING NORMS
}

\section{Vojtěch Bartoš}

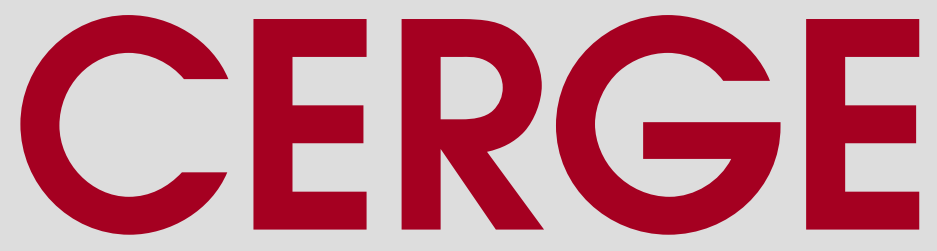




\title{
Working Paper Series $\quad 557$ (ISSN 1211-3298)
}

\section{Seasonal Scarcity and Sharing Norms}

\author{
Vojtěch Bartoš
}

\section{CERGE-EI}

Prague, January 2016 
ISBN 978-80-7343-364-2 (Univerzita Karlova v Praze, Centrum pro ekonomický výzkum a doktorské studium)

ISBN 978-80-7344-368-9 (Národohospodářský ústav AV ČR, v. v. i.) 


\title{
Seasonal Scarcity and Sharing Norms*
}

\author{
Vojtěch Bartoš ${ }^{\dagger}$ \\ CERGE-EI in Prague
}

January 2016

\begin{abstract}
Sharing provides one of few sources of insurance in poor communities. It gains prominence during adverse shocks, often largely aggregate, when it is also costliest for individuals to share. Yet it is little understood how scarcity affects individual willingness to share and willingness to enforce sharing from others, an important ingredient in sustaining prosocial behavior. This is what this paper examines. I conduct repeated within-subject lab-in-the-field experiments among Afghan subsistence farmers during a lean and a postharvest season of relative plenty. These farmers experience seasonal scarcities annually. Using dictator and third party punishment games I separate individual sharing behavior from enforcement of sharing norms. While sharing exhibits high degree of temporal stability at both the aggregate, and, to a large extent, at the individual level, the enforcement of sharing norms is substantially weaker during the lean season. The findings suggest that the farmers are capable of sustaining mutual sharing through transitory periods of scarcity. It remains an open question whether exposure to unexpected shocks or prolonged periods of scarcity might result in breakdown of prosociality due to loosened sharing norms enforcement on a community level.
\end{abstract}

JEL Classification: C93, D63, I32, Z13

Keywords: Afghanistan, Scarcity, Seasonality, Sharing, Social norms

${ }^{*}$ I thank Michal Bauer, Karna Basu, Jana Cahlíková, Alexander W. Cappelen, Lee Cronk, Dirk Engelmann, Ernst Fehr, Randall Filer, Peter Katuščák, Andreas Ortmann, Gérard Roland, Ondřej Rydval, Jakub Steiner, Bertil Tungodden and audiences at NHH Bergen, UC San Diego, NYU, Rutgers University, CERGE-EI, GDN (New Delhi), SEEDEC (Bergen), NIBS (Nottingham), IMEBESS (Toulouse), and ESA (Heidelberg) for invaluable comments. I am grateful for the hospitality and logistical support of the NGO People in Need, Afghanistan. I also thank Akram Rasaa, Mohibullah Mutahed, Kamran Shahzad and Yar Mohammad Rajabi for excellent research assistance. Financial support from GAUK (no. 46813), Czech Science Foundation (no. 13-20217S), and the GDN (RRC13+11) is gratefully acknowledged. All errors and mistakes are mine. Disclaimer: This research was supported by a grant from the CERGE-EI Foundation under a program of the Global Development Network. All opinions expressed are those of the author(s) and have not been endorsed by CERGE-EI or the GDN.

${ }^{\dagger}$ Email: vojtech.bartos@cerge-ei.cz

${ }^{\ddagger}$ CERGE-EI, a joint workplace of Charles University in Prague and the Economics Institute of the Czech Academy of Sciences, Politickych veznu 7, P.O. Box 882, 11121 Prague 1, Czech Republic. 


\section{Introduction}

Sharing is a well documented source of informal insurance in village economies or poor communities where it frequently substitutes for formal insurance. It gains the uppermost importance during periods of scarcity; nontheless, this is the period when sharing becomes most costly for those who share. This trade-off makes our understanding of how scarcity affects sharing an open question. To sustain sharing, societies require its members to punish shirkers (e.g., Boyd, Gintis, Bowles \& Richerson, 2003; Fehr \& Fischbacher, 2004a). ${ }^{1}$ When the threat of punishment is missing, individuals disciplined to behave cooperatively start behaving selfishly, commencing the cycle of social erosion. Another question thus arises: Does scarcity affect individual willingness to engage in enforcement of sharing? This paper addresses both these questions.

Previous research has examined if people share (Townsend, 1994; Morduch, 1995; Jalan \& Ravallion, 1999), why they share (List, Berrens, Bohara \& Kerkvliet, 2004; Leider, Mobius, Rosenblat \& Do, 2009; DellaVigna, List \& Malmendier, 2012), and who they share with (Barr \& Genicot, 2008; Attanasio, Barr, Cardenas, Genicot \& Meghir, 2012), or a combination of the three (Ligon \& Schechter, 2012), but so far there are only very few studies examining when to share and no economic studies that would causally determine a link between scarcity, and willingness to share and enforce sharing norms.

I establish this link by examining the sharing and norm enforcement behavior of small-scale farmers in rural Afghanistan during a seasonal cycle of scarcity and relative abundance. A majority of the one billion people employed in agriculture in Asia and SubSaharan Africa are subsistence farmers dependent on highly volatile harvests, frequently affected by both aggregate and idiosyncratic shocks. This population is the most affected by seasonal scarcities (Sahn, 1989; Devereux, Swan \& Vaitla, 2008; FAO, 2012; Khandker \& Mahmud, 2012). ${ }^{2}$ The cyclical nature of agricultural production together with a limited insurance, credit and savings markets, and a low quality of storage technologies exposes many to seasonal scarcities (Basu \& Wong, 2015). Apart from seasonal migration (Bryan et al., 2014), mutual willingness to share resources with others remains one of few coping strategies. ${ }^{3}$ Since much of the world's population is subject to agricultural

\footnotetext{
${ }^{1}$ Willingness to engage in costly third-party punishment in which materially uninterested individuals are willing to forego gains to punish unfair behavior has been documented in economic experiments (Fehr \& Fischbacher, 2004b; Bernhard, Fischbacher \& Fehr, 2006) and was found to be positively correlated with the level of altruistic sharing in a cross-cultural study (Henrich, McElreath, Barr, Ensminger, Barrett, Bolyanatz, Cardenas, Gurven, Gwako, Henrich, Lesorogol, Marlowe, Tracer \& Ziker, 2006). Fehr \& Gächter (2000) show that cooperation can be sustained only if subjects have an opportunity to punish free-riders and gradually breaks-down once the opportunity is removed, and, reassuringly, that cooperation can be restored once the enforcement mechanisms are reintroduced. The forms of punishment may range from physical attacks on noncooperators, through gossip, all the way to ostracism of the non-cooperators. These forms of punishment are well documented in anthropology (Cronk, Chagnon \& Irons, 2000), ethnography (Fessler \& Navarrete, 2004) or economic history (Greif, 1993). Gürerk, Irlenbusch \& Rockenbach (2006) show that societies with punishment mechanisms are evolutionary more competitive compared to societies where punishment mechanisms are lacking.

${ }^{2}$ See Bryan, Chowdhury \& Mobarak (2014) for an extensive list of references documenting regular seasonal scarcities around the world.

${ }^{3}$ While food sharing is common in hunter-gatherer small-scale societies, sharing of resources in more advanced communities may operate through provision of informal loans on flexible interest rates with flexible repayment dates. Such behavior is frequently observed in poor communities (Collins, Morduch, Rutherford \&
} 
cycles, it is of interest to learn how sharing concerns unfold at different points of the cycle.

A major challenge in examining sharing over time is that kinship, reputational concerns, reciprocity, or fear of retribution all confound the observed sharing behavior. Using observational data or narrative evidence, it is virtually impossible to distinguish between reputation-driven third-party punishment motivated by selfish motives from that driven by altruistic goals, not to say that quantifying social norms for cross-temporal comparison is inconceivable without using experimental methods. In order to overcome these issues, I conducted a controlled lab-in-the-field experiment using a one-shot dictator game (Kahneman, Knetsch \& Thaler, 1986) and a one-shot dictator game with a third party punishment option (Fehr \& Fischbacher, 2004b) examining temporal stability of sharing behavior and of sharing norm enforcement among 207 subsistence farmers in northern Afghanistan. ${ }^{4}$ This remote rural society is exposed to dramatic aggregate and idiosyncratic seasonal shocks to consumption (NRVA, 2008). I conducted two rounds of experiments with the same participants: one during the lean season and one during the post-harvest season. This provides me with a unique opportunity to inspect within-subject behavioral changes when exogenously exposed to more or less scarcity.

Previous literature offers conflicting views as to whether sharing increases, remains constant, or decreases with resource scarcity. Moreover, to my knowledge, no study examining effects of scarcity on other-regarding behavior differentiates between individual willingness to share and the willingness to engage in enforcement of sharing norms. In other words, whether the behavioral change operates through temporal instability of preferences or through a coordination problem on a community level.

Microeconomic theory would suggest that if the cost of sharing increases in the period of scarcity - which is plausible assuming concavity of the utility function over income or consumption - sharing behavior should decline. ${ }^{5}$ Yet experiencing scarcity also implies increased benefits to the receiver, who is more likely to be in need. ${ }^{6}$ Experimental, empirical, and theoretical literatures all give ambiguous predictions as to whether sharing or pro-social behavior in general increases or decreases during the period of scarcity.

On the one hand, Ostrom, Burger, Field, Norgaard \& Policansky (1999) argue that scarcity of resources encourages more efficient institutional organization and enforcement mechanisms facilitating sustainable resource use. Anthropologists report narrative evidence of increased cohesion in both small- and large-scale societies facing seasonal food shortages (Evans-Pritchard, 1969; Lévesque, de Juriew, Lussier \& Trudeau, 2000). Laboratory experiments support this by showing that extraction rates in a common pool

\footnotetext{
Ruthven, 2009).

${ }^{4}$ Economists and social scientists have been using dictator games to measure sharing motives (Camerer, 2003). To address possible external validity concerns, Barr \& Genicot (2008) show that risk-sharing decisionsnamely risk-sharing network formation-observed in a similar experimental task reflect actual risk-sharing behavior in Zimbabwean villages.

${ }^{5}$ Andreoni \& Miller (2002) show that a rising price of sharing indeed leads to a drop in sharing. Similarly, Fehr \& Fischbacher (2003) conclude that with increasing cost of sharing, individuals become less willing to share in a dictator game or contribute to the public good in a public goods game.

${ }^{6}$ Engel (2011) shows in a comprehensive survey of dictator games that recipients' neediness increases amounts shared.
} 
game drop when resources become scarce (Osés-Eraso \& Viladrich-Grau, 2007).

On the other hand, scarcity is also shown to affect prosocial behavior negatively. Scarcity of common pool resources leads to more free-riding in ground water usage (Varghese, Veettil, Speelman, Buysse \& Van Huylenbroeck, 2013) or in fisheries extraction rates (Maldonado, Moreno-Sánchez \& del Pilar, 2009). Grossman \& Mendoza (2003) show theoretically that common pool resources are extracted faster when survival is at stake. This is consistent with documented cases of increased selfishness during extreme food scarcities, such as famines or wars (Dirks, 1980; Turnbull, 1972). Scarcity further results in general acceptance of loosened ethical behavior (Oster, 2004; Miguel, 2005), suggesting that social norms respond to the changing environment. Less dramatic but equally important for the present study, Wutich (2009) shows that social networks loosen during dry seasons.

As for the importance of punishment behavior, groups ranging from small scale societies to large nation states are able to sustain cooperation if individuals are willing to engage in prosocial acts, together with enforcing prosociality from others, even against their own direct self-interest (Gintis, 2000; Henrich \& Boyd, 2001; Boyd et al., 2003). Norm enforcement is especially critical in periods of shocks when the probability of the group survival decreases, such as during wars, famines, or periods of scarcity, as in the case of this paper, when reputational motives are weak or non-existent. Enforcement reduces the proliferation of selfish types invading the population and thus increases prosociality.

Although the evidence of altruistic third-party enforcement of sharing in economic experiments is plentiful (Fehr \& Fischbacher, 2004b; Henrich et al., 2006; Bernhard et al., 2006), the literature examining its dynamics with environmental changes is scarce. Only Gneezy \& Fessler (2012) get close by examining the dynamics of second-party enforcement of cooperation with the exposure to conflict. They show that the enforcement intensified during the Israeli-Hezbollah war compared to a prior period or in the immediate aftermath. In their case the threat to the community came from an identifiable external threat. In the case of seasonal scarcity the threat comes from non-cooperative individuals within. Overall, the predictions as to whether scarcity is conducive or detrimental to sharing and its enforcement are unclear.

My findings are that despite substantial changes in income, consumption, health, and perceptions of stress within individuals across the lean and post-harvest seasons, sharing, measured by the amount passed in the dictator game, as well as in the third party punishment game, remain unchanged at the aggregate level and fairly stable at the individual level. However, the enforcement of sharing norms, measured by the willingness and the intensity of costly punishment of unfair allocations by monetarily uninterested third parties, are significantly weakened during the lean season. The drop in punishment of non-desirable behavior reflects a change in social norms rather than a shift in statedependent individual preferences and can be attributed either to increased uncertainty about the intentions of others or to increased grievances suppressing expression of altruistic punishment, with limited evidence favoring the latter. The observed results are quantitatively similar for two different groups represented in the study — Sunni Tajiks and 
Shia Hazaras - allowing for more generalizable statements about the findings presented.

Albeit that I do not observe a change in dictators' willingness to share across seasons it is plausible that during a prolonged period of weak enforcement under scarcity sharing behavior would drop. This is an established finding in laboratory experiments where prosocial behavior gradually deteriorates with unavailable enforcement mechanisms (e.g., Fehr \& Fischbacher, 2004a). ${ }^{7}$

There have only been a few experimental studies assessing the effect of scarcity on prosocial behavior. The present experiment is, to my knowledge, the first to examine temporal stability of sharing in a setting where dramatic changes to consumption might possibly lead to changes in individual behavior. Second, it is the first paper examining temporal dynamics of sharing norm enforcement using the third-party punishment game.

\section{Related literature}

My paper speaks to different streams of literature:

First, recently a literature on the endogeneity of social preferences has been emerging. Social preferences have been found to be shaped in early childhood (Fehr, Bernhard \& Rockenbach, 2008) through adolescence (Almås, Cappelen, Sørensen \& Tungodden, 2010) and vary markedly across cultures (Henrich, Ensminger, McElreath, Barr, Barrett, Bolyanatz, Cardenas, Gurven, Gwako, Henrich, Lesorogol, Marlowe, Tracer \& Ziker, 2010). All these studies examine long-term processes of preference formation, whereas the current paper analyzes possible dynamics over short-term periods of scarcity.

Second, conflict has been described as an important factor shaping human prosociality (Choi \& Bowles, 2007) and experimental studies confirmed the causal link between exposure to warfare and parochial altruism (Voors, Nillesen, Bulte, Lensink, Verwimp \& Soest, 2012; Bauer, Cassar, Chytilová \& Henrich, 2014). Parochialism induced by exposure to inter-group conflict differs from the scope of the present study in that war is an unexpected event in which the threat comes from outside of the society. The present study speaks to possible short-term effects of resource scarcity on sharing behavior. This also differs from recent studies examining effects of unexpected natural disasters on social preferences (Cameron \& Shah, 2015).

Third, the paper speaks to the emerging experimental literature examining temporal stability of preferences. Recent studies have shown that time preferences (Meier \& Sprenger, 2015), risk preferences (Andersen, Harrison, Lau \& Elisabet Rutström, 2008), and cooperative preferences (Volk, Thöni \& Ruigrok, 2012) remain stable over time. However, all of the studies mentioned were carried out in stable environments of developed countries. My study is the first of its kind to provide evidence of temporal stability of sharing preferences in an environment exposed to substantial, yet to some extent expected environmental shocks.

Lastly, the paper speaks to the sparse literature examining temporal dynamics of

\footnotetext{
${ }^{7}$ Similarly, Gneezy \& Fessler (2012) link the increased willingness to punish in-group non-cooperators during wartime to evolution of human cooperation despite the fact that they do not observe any change in the ultimatum game transfers.
} 
social norms using economic experiments. To my knowledge, only Gneezy \& Fessler (2012) examine changes in enforcement of cooperation during wartime.

The paper closest to mine is Prediger, Vollan \& Herrmann (2014). They examine the effect of resource scarcity on cooperation and anti-social behavior among Namibian villagers using economic experiments in their natural environment where they are exposed to different levels of resource scarcity. The study shows that anti-social behavior is higher in the area exposed to higher scarcity of resources, but does not find any difference in levels of cooperation across the areas. ${ }^{8}$ Their study, however, differs from mine in several aspects. First, it does not differentiate between the role of individual prosociality and communal enforcement but rather concentrates on behavioral differences across communities in public goods and joy-of-destruction games. Second, their study considers differences in behavior across two locations exposed to different environmental conditions in a long term, while my study examines short-term effects of scarcity on cooperation within a particular community, with villagers participating repeatedly in an experiment when their environmental conditions are changing exogenously.

Another closely related study is that of Fisman, Jakiela \& Kariv (2015). They examine the effect of the 2008 Great Recession on sharing behavior to find that people become more selfish after experiencing an economic downturn, both actual and a labinduced. Their study differs from mine in several respects. First, it considers the sharing and not the enforcement part. Second, the study is conducted in a developed country where recession might trigger different responses than in a developing country. Third, their study examines behavior of different groups of individuals, rather than observing the same individuals over time as I do in this paper.

The method I employ resembles that of Mani, Mullainathan, Shafir \& Zhao (2013) who examine the effect of scarcity on cognitive abilities in a population of Indian sugarcane farmers. Mani et al. observe their participants over the pre- and post-harvest seasons and compare the results before and after. The present study aims to contribute to this stream of literature by examining the temporal stability of sharing and of sharing norms enforcement in a highly volatile environment of Afghanistan.

\section{Experimental design}

\subsection{Sample selection}

The participants were recruited for the experiments in 10 randomly selected villages in the Marghzar and Amrakh areas of Zari district in Balkh province, northern Afghanistan, a remote area at high elevation. With more than 60 percent of the population living below the poverty line, Balkh is one of the poorest provinces in Afghanistan (NRVA, 2008). The vast majority of the local population subsists on agricultural production or agricultural labor. We invited all land-owning farmers, a maximum of one adult person per household was allowed. The head of the household - the main bread winner - was strongly preferred. Due to cultural constraints, only males were invited.

\footnotetext{
${ }^{8}$ The cooperation behavior results are only reported in an earlier working paper.
} 
To answer the question whether sharing and enforcement of sharing norms vary with exposure to resource scarcity I exploit the fact that farmers in this area face annual seasonal food shortages. I conducted 20 experimental sessions in 10 villages with 291 adult male farmers in the lean season of April 2013 and an additional 20 sessions in the same villages with 207 participants who we managed to contact also in the postharvest season in October 2013. ${ }^{9}$ To overcome possible "calendar effects", I conducted the experiments outside of major Islamic holidays, harvest time, or bazaar days and no significant events were reported when we conducted the experiments. In the postharvest season we also recruited an additional 82 fresh participants to substitute for the participants who dropped out. I do not use the fresh participants' data in the main analysis. Each session was conducted with 12 or 15 participants. The participation in each experimental round was voluntary and the participants could leave at any time. All participants decided to complete the tasks within each round.

Demographic characteristics for the sample of the 207 participants participating in both experimental rounds are presented in Table 1. Half of the sample are Sunni Muslims (51 percent) mainly of Tajik ethnic origin and the other half is Shia Muslims of predominantly Hazara ethnic origin, all living in completely segregated areas. ${ }^{10}$

It is important to note that 84 subjects who participated in the first experimental round did not participate in the second experimental round. Out of them 62 (74 percent) migrated either to Iran, to Mazar-e-Sharif, Kabul, or to another village for seasonal work. Only the remaining 22 (26 percent) did not show up either because of working elsewhere at the time of the experiment, being sick, or attending a wedding at the time of the assigned experimental session. Reassuringly, no one declined to participate due to reasons related to the experiment.

Note that the selective attrition would systematically bias the results only if it were correlated with the stability of sharing and with willingness to engage in third-party norms enforcement.

\subsection{Seasonal effects}

There is vast evidence that farmers in developing countries are exposed to substantial fluctuations in incomes and consumption over the year (Devereux et al., 2008; Khandker $\&$ Mahmud, 2012). Table 2 presents the seasonal differences in observable characteristics among the sample of participants in both seasons. The data show that seasonality matters indeed. The participants' average monetary income in the previous month in the lean season is only 71 percent of the post-harvest season income (2078 AFN vs. 2929 AFN). Also, 59 percent of participants reported having no monetary income in the lean season compared to 38 percent of participants in the post-harvest season. Smoothing consumptions with own income across seasons is unlikely due to almost non-existent savings in the area.

\footnotetext{
${ }^{9}$ An additional community mobiliser was recruited to assist with the previous round participants tracking.

${ }^{10}$ I do not control for religion in the analysis because individual religious affiliation is perfectly correlated with village affiliation. I use village fixed effects in regressions that thus control for possible effects of religion too.
} 
Meat is consumed less frequently during the lean season. The share of people in debt increases from 70 percent in the post-harvest season, already high, to 86 percent in the lean season. The participants also seem to have less money available for lending out during the lean season as the share of subjects lending money to others decreases from 39 percent in the post-harvest season to 29 percent in the lean season. ${ }^{11}$ Further aggravating the severity of the lean season, the participants report being much more likely to be unable to work due to injury or illness, they feel generally more stressed, and are affected by shocks such as crop pests and diseases, livestock diseases, as well as human diseases. Irrespective of the season, 25 percent of the participants report that someone from their household has been out of the village, migrating for work. ${ }^{12}$

Figure 1 shows that the participants are well aware of the seasonal swings over the year. Responding to a question to select three months of a year that are generally most difficult for them to cope with and three months of a year that are generally least difficult for them to cope with, most participants perceive the winter and the spring months (the lean season) as the most difficult to live through and the summer and the autumn months (the harvest and the post-harvest season) as the best months of a year.

\subsection{Experimental tasks}

Each experimental session consisted of two tasks. A one-shot dictator game (DG; Kahneman et al., 1986) and a one-shot dictator game with a third party punishment option, the third-party punishment game (TPPG; Fehr \& Fischbacher, 2004b; Bernhard et al., 2006). To control for order effects I randomly manipulated the order of tasks. The participants were rematched after each task and across rounds in order to avoid strategic behavior and possible reciprocal concerns. After the experiment each participant was surveyed.

The DG allows me to examine the temporal stability of individual sharing behavior in the absence of confounds of kinship, reciprocity, reputation building or the fear of social sanctioning for non-desirable behavior. In this quasi-game a dictator, Person A (PA), divides a given endowment (10 experimental currency units, ECUs) between himself and a passive receiver, Person $\mathrm{B}(\mathrm{PB})$. PB is also one of the participants in the same experimental session as $\mathrm{PA}$, but he receives no endowment and only learns the final allocation of money. The game allows for 11 strategies, as only whole units can be passed. The allocation depends entirely on PA's own willingness for unconditional sharing under the veil of anonymity, as his identity is never revealed to PB. Thus, the individual is motivated to reveal his true sharing preferences. For simplicity, the ECUs in the game are represented by money slips evoking 20 AFN banknotes, not by real money. The conversion rate is $1 \mathrm{ECU}=20 \mathrm{AFN}$.

\footnotetext{
${ }^{11}$ As other studies from developing countries have found, many people are lenders and borrowers at the same time (Collins et al., 2009).

${ }^{12}$ Although statistically insignificant, the sample of participants in the lean season who did not participate in the post-harvest season were more likely to report that someone from their household has currently been out of the village migrating for work (32 percent vs. 25 percent). This suggests that these subjects' households are more dependent on income from seasonal work outside of the village.
} 
In order to test the temporal stability of sharing norm enforcement, I administer a TPPG. The game allows a monetarily uninterested third party-Person $\mathrm{C}(\mathrm{PC})$ - to observe the sharing behavior of a dictator-PA - in a DG where even PA and PB are aware of PC's presence. First, PA decides how much of the 10 ECUs of his endowment to pass to $\mathrm{PB}$ who has no endowment as in the DG described earlier. PB only learns PA's final decision and has no control over it. Second, PC may decide to punish the dictator for his behavior but only at a cost to himself. Each PC is endowed with 5 ECUs and he can either refrain from punishment or pay 1 or 2 ECUs to subtract 3 or 6 ECUs of PAs payoff, respectively. This distribution ensures that in a situation when PA behaves as an egalitarian and PC decides not to punish such behavior, all players leave the experiment with 5 ECUs. However, PCs do not observe PAs' actual behavior. Rather, I elicit their reaction to all possible behaviors of PA using a strategy method. PC's willingness to pay to punish provides me with a direct measure of willingness to engage in altruistic enforcement of specific sharing norms. The variable of interest is the minimum acceptable PA offer to PB that is not punished by PC. Further in the text, I denote the minimum acceptable offer as MAO (originally used in Henrich et al., 2006).

\subsection{Experimental procedures}

The experiments were announced one day in advance. The villagers were informed that an experiment requiring a commitment of four hours of their time will be conducted in their village for which they will earn at least 100 AFN (approximately 2 USD) as a show-up fee, but possibly more. ${ }^{13}$ All interested farmers were gathered in a community center (a guesthouse, mosque, or a village leader's house) the morning just before the first session. If more villagers showed up for an experimental session than we could accommodate, we either invited them for another session if there was one conducted in the same village or we ran a lottery in which we selected the participants by chance. Consequently, the actual participants randomly picked an ID number, which determined their role in the experiment (See Figure A1).

As is common in economic experiments carried out with low-literacy subjects, the instructions were first explained in a group using practical examples and visual aids (See Figure A2), and only then were the actual experiments carried out with the subjects individually (See Figure A3). ${ }^{14}$ Before making their actual decisions, all participants were shown several examples, were allowed to practice several scenarios themselves, and were then asked to answer several control questions. The research assistants explained the task until the participants fully understood and the experiments were carried out

\footnotetext{
${ }^{13} \mathrm{An}$ average daily wage is $150 \mathrm{AFN}$, but it is not possible to find work every day in the area. During the off-season work is particularly scarce. Importantly for my study, the size of the initial endowment does not seem to influence the relative transfers in dictator games to the extent that might invalidate the results of the present study (Engel, 2011, p. 592). In order to validate this claim, I conducted several experimental sessions with stakes increased by 50 percent in the 2013 lean season only to find that the relative transfers do not differ from the transfers in games with the original endowment size. The 50 percent increase reflected the reported 50 percent increase in prices of most common consumption goods during the lean season compared to the post-harvest season. Results are available upon request.

${ }^{14}$ The instructions and procedures I used are inspired by Bernhard et al. (2006) and by Henrich et al. (2006). Instructions are available in the Appendix C.
} 
only after participants' full comprehension. Only one participant failed to pass the comprehension test due to hearing problems, not the inability to comprehend the task. The instructions were presented orally in the local language, Dari, and were translated back to English.

Communication in all rounds of experiments was not allowed and all tasks were strictly anonymous. Only one task was randomly selected for the payment to avoid strategic play across experiments. This procedure was revealed to the participants in the instructions.

Although the participants received their payments at the end of each experimental session they did not receive any feedback on their actions and the actions of other players. Average earnings were about 190 AFN including the show-up fee (100 AFN), which is slightly above the average daily wage of a casual laborer.

\section{Results}

This section I first discuss both aggregate and individual-level temporal stability of sharing behavior. Then I present the behavioral change in willingness to enforce sharing norms over time.

\subsection{Temporal stability of sharing behavior}

I begin by discussing the temporal stability of sharing behavior. First, I present the aggregate results of sharing behavior. Second, since the design of the experiment allows me to observe the sharing behavior within the same individual across seasons, I present the results on the within-subject stability of sharing.

Does the aggregate sharing behavior differ across seasons? Columns 1 and 3 in Table 3 show that in the DG the PAs transferred on average 3.03 ECUs to PBs in the lean season compared to 3.22 ECUs in the post-harvest season, the difference being statistically insignificant (Mann-Whitney U-test, MWT: $\mathrm{p}=0.48, \mathrm{n}=136$ ). Similarly for the TPPG, I find that an average transfer of 2.87 ECUs in the lean season and 3.10 ECUs in the post-harvest season, the difference being again statistically insignificant (MWT: $\mathrm{p}=0.41, \mathrm{n}=136)$.

I test the temporal stability of sharing behavior using the following regression model:

$$
T_{i t}=\alpha+\beta L S_{i}+\gamma X_{i t}+\varepsilon_{i t}
$$

where $T_{i t}$ is the amount passed by the individual $i$ in the experimental game in the period $t$, which is either the lean season or the post-harvest season. $L S_{i}$ is the treatment variable equal to 1 in the lean season, $X_{i t}$ is a set of individual characteristics ${ }^{15}$, and $\varepsilon_{i t}$

\footnotetext{
${ }^{15}$ In the main estimations I either omit the control variables, add only a set of (time-invariant) village dummy variables, or add both village dummy variables and individual level characteristics such as age, number of years in school, number of individuals living in the individual's household, individual's income in the previous month, and the comprehensive poverty index proxy. The poverty index at a given point of time is estimated using the principal component analysis. The $1^{\text {st }}$ principal component of each poverty measure for a given season is constructed using current individual income, animals owned, assets owned, variability of food consumed, meat
} 
is the error term.

Table 4 shows that the behavior across seasons remains stable both in the DG and the TPPG when using a regression framework. The first model (Columns 1 and 4 in Table 4) does not include any controls. The second model (Columns 2 and 5) controls for village-specific effects, as the village fixed effects explain about 16 percent or 13 percent of the variance in the DG or the TPPG transfers, respectively. ${ }^{16}$ Finally, the third model (Columns 3 and 6) further controls for additional individual level controls. In neither case is the variable lean season statistically significantly different from zero and we can conclude that the sharing behavior does not change across seasons for either the DG or the TPPG. ${ }^{17}$

Figure 2 examines the cumulative distributions of respective amounts transferred in the DG (Panel A) and the TPPG (Panel B) across the two seasons. Apart from the difference in the frequency of PAs sending 3 ECUs both in the DG (difference in frequencies across rounds borderline significantly different from zero, $p=0.09$ ) and the TPPG (marginally insignificant, $\mathrm{p}=0.13$ ), the distributions are identical, a necessary condition for stability of preferences. The Epps-Singleton Two-Sample Empirical Characteristic Function (ESCF) test cannot reject the equality of distributions for neither the DG $(\mathrm{p}=0.22)$, nor the TPPG $(\mathrm{p}=0.34) .{ }^{18}$

Finding 1: On the aggregate level I find that the sharing behavior in the $D G$ and the TPPG does not vary with short term exposure to scarcity.

I now turn to the analysis of the within-subject stability of sharing. In total, we successfully tracked 68 PAs. These participants were exposed to the same experimental procedure in both the lean season and in the post-harvest season, six months later.

I examine the correlations in sharing behavior across seasons and individual changes in sharing behavior. I compare the actual changes in sharing behavior to a reference situation in which I treat the distribution of transfer choices as randomly allocated across individuals. First, I describe the stability of sharing behavior in the DG and then I comment on the stability of behavior in the TPPG.

Panel A of Figure 3 presents the histogram of changes in individual behavior in the

eaten in a given week, days unable to work due to illness or injury in the previous month, a short version of the perceived stress score (Cohen, Kamarck \& Mermelstein, 1983), and dummy variables representing unusual health shocks to humans, animals, and plants. Note that the results presented in this paper are robust to the use of different sets of controls (additional analysis available upon request).

${ }^{16}$ See Table A1.

${ }^{17}$ In the main regressions I use the commonly reported OLS with clustered standard errors. The results are robust to using ordered probit, which takes into account the discrete nature of the dependent variables. See Tables A2 and A3 for the replication of OLS results.

${ }^{18}$ The distribution of DG transfers fits between the classifications of the developing country and an indigenous society subject pool classification used in the DG meta study by Engel (2011). The Afghan PAs are much more likely to pass positive amounts to PBs than the Western subjects (91 percent versus 67 percent in the Western societies, 81 percent in the developing countries and 95 percent in the primitive societies), slightly less likely to pass equal share (21 percent versus 20 percent Western, 27 percent developing and 28 percent primitive societies), but no one in this sample passes the entire pie unlike 5 percent of the Western subjects and 1 percent both in developing countries and in primitive societies. Similar comparison for TPPG transfers is not possible, since the game has not been used so extensively and no effort to conduct a meta-analysis has been made. 
DG, specified as a difference between the lean and the post-harvest season transfers. It reveals that more than 30 percent of individual decisions in the DG remained constant across both seasons. Moreover, almost 65 percent of decisions remained within a change of one ECU or 10 percent of the PAs endowment. The correlation between DG transfers in the lean season and in the post-harvest season is $0.52(\mathrm{p}<0.01)$. Such stability is relatively high compared to other studies examining temporal stability of preferences. ${ }^{19}$

It is possible that the result presented here as a proof of temporally stable sharing behavior could arise as a confound, and would arise even if the DG choices were drawn randomly. We can rule out this possibility, as each choice from the entire set of possible transfers would have to be represented uniformly, which is clearly not the case without any need for statistical testing. On the other hand it is well plausible that due to the limited choice space observed in the cumulative distribution of choices in Figure 2 with the majority (75 percent) of PAs transferring between 2 and 5 units, it could be that the temporal stability of the sharing behavior is an artefact of the experiment. In order to rule out this possibility, I conduct an exercise in which I randomly assign choices from the set of all realized transfers in the post-harvest season to PAs. After reshuffling the PA choices 10000 times, the average number of equal choices across both seasons is around 15.6 percent, and 42.5 percent of decisions remain within a change of one unit, much lower than the actually observed values.

Next, I discuss the within-subject stability of TPPG results. Although statistically significant $(\mathrm{p}=0.07)$, the correlation of individual behavior in the TPPG across seasons is 0.22 , much lower than the correlation discussed in case of the DG. Yet even such correlation would be generally accepted as fairly stable over time in the psychological literature (see footnote 19). Panel B in Figure 3 shows that only 13 percent of individuals sent equal amounts in both seasons, even though the share of individuals with changes within a margin of one unit reaches over 55 percent.

In a similar exercise as presented for the DG, I simulate what would have happened had the distribution of TPPG transfer choices been randomly drawn from the distribution of choices in the post-harvest season to see how many individuals would have sent equal split in such hypothetical case. The average share of participants sending equal amounts in both seasons after random reshuffling in 10000 repetitions is over 16 percent. This implies that the results I obtain in my experimental data are no better than due to random chance. More reassuringly, conducting the same exercise for the variable indicating a transfer difference within a margin of one ECU, the share is about 43 percent, indicating some degree of individual stability within this extended margin.

Finding 2: Transfers in the DG are temporally stable within individuals, suggesting stability of sharing. To a lesser extent I also observe within individual temporal stability

\footnotetext{
${ }^{19}$ Literature in psychology examines the stability of preferences in much more detail than economics does. Surveys examining stability of single cross-situational measures usually report temporal stability in a range between 0.2 to 0.3 (see e.g., Block, 1983; Jessor, 1983) and perceives such correlations as indicating relatively stable preferences, while within this interval. Similarly to my findings, Meier \& Sprenger (2015) report a correlation of 0.5 in individual time preference choices in an experiment repeated twice over a year with the same set of subjects and label such correlation as high.
} 


\subsection{Temporal stability of norm enforcement}

Now I analyse the behavior of PCs in the TPPG in order to understand the dynamics of sharing norm enforcement with exposure to scarcity of resources. I first discuss the aggregate punishment results, and I examine the within-subject results later.

Figure 4 shows the distributions of PCs' minimum acceptable offers in the TPPG (MAO) in both the lean and the post-harvest seasons. MAO is the lowest PA's transfer to $\mathrm{PB}$ that a $\mathrm{PC}$ would accept. ${ }^{20}$ For example, if a PC decided to engage in either type of punishment of the PA for sending anything less than or equal to 2 ECUs to PB, then the MAO for this PC is equal to 3 ECUs. The lowest value for MAO is 0 ECU if PC decides not to punish any kind of PA's behavior. I was able to elicit MAO for 60 out of 71 PCs in the lean season (85 percent) and for 63 out of 71 PCs in the post-harvest season (87 percent). ${ }^{21}$ The subjects for whom I am unable to construct MAO behaved in an inconsistent way, punishing transfers largely at random without any systematic pattern. In the analysis below I use the 123 valid observations.

Figure 4 shows that the Afghan participants in the role of PCs were willing to engage in costly punishment of PAs who were not willing to share enough. Regardless of season, the probability of punishing PAs increases with PAs' transfers approaching zero. ${ }^{22}$

Unlike in the case of PAs' transfers, the punishing behavior of PCs is not temporally stable. Figure 4 shows that there is a significant decrease in the willingness to punish low offers from the post-harvest to the lean season. Speaking about magnitudes, PCs in the post-harvest season were on averege not punishing offers equal to 3.03 ECUs and higher, while in the lean season the average MAO dropped significantly to 1.35 ECUs (Columns 1 and 3 in Table 3), reaching the levels of average transfers in the DG and TPPG. The difference in MAO across rounds is highly statistically significant (MWT: $p<0.01$, $\mathrm{n}=123$ ). I can also reject the equality of MAO distributions over time (Epps-Singleton, $\mathrm{p}<0.01)$.

Table 5 shows that the increase in willingness to punish remains highly significant and of a similar magnitude even in a regression framework. Again, I use the model specified in Equation 1 where the $T_{i t}$ now stands for the MAO by individual $i$ in time $t$. In the first model I do not control for any additional characteristics (Column 1 in Table 5), in the second model I control for the village level fixed effects (Column 2), and in the third model I control for both the village level fixed effects and the individual level characteristics together (Column 3). In all specifications MAO remains statistically significantly lower in the lean season round.

Importantly, the behavior of PCs is also reflected in beliefs of others. Apart from the main experimental task, I also measured beliefs using several incentivised questions.

\footnotetext{
${ }^{20}$ In this text I do not differentiate between the intensity of punishment, but the results presented would only be strengthened by accounting for it. These results are available upon request.

${ }^{21}$ In terms of the task comprehension, this makes my sample comparable to that of Henrich et al. (2006), who were able to assign MAO to 92 percent of their sample.

${ }^{22}$ Such a pattern emerges even if we include the inconsistent punishers (analysis available upon request).
} 
Regarding the punishment, I asked the participants whether they believe that most PCs in the current experimental session would punish a PA who decides to transfer zero ECUs. The results are presented in Table 3. Although insignificantly, the beliefs of PBs (lean season 68 percent vs. post-harvest season 78 percent; MWT: $\mathrm{p}=0.18, \mathrm{n}=136$ ) match the actual behavior of PCs and is of similar magnitude as beliefs of PCs about other PCs' willingness to punish zero transfers in their experimental session (lean season 65 percent vs. post-harvest season 79 percent; MWT: $\mathrm{p}=0.06, \mathrm{n}=142$ ). This suggests that the behavioral change across seasons is more generally considered in the population and is not just an artefact of the experiment among the group of PCs. This conclusion has to be taken with some caution, since the PAs beliefs do not match that of PBs and PCs. Unlike the other participants, the PAs expect the punishment of zero transfers in 70 percent of cases regardless of season (MWT: $\mathrm{p}=0.89, \mathrm{n}=135$ ).

As in previous studies (Fehr \& Fischbacher, 2004b; Bernhard et al., 2006; Henrich et al., 2006), the Afghan farmers are willing to engage in costly altruistic punishment for which they have to give up 20 percent or 40 percent of their endowment to punish non-desirable behavior. In terms of daily incomes, the amounts are equal to giving up 13 to 26 percent of average daily incomes to discipline others, a substantial amount given the tight budgets of the population studied. Overall, 93 percent of the PCs for whom I am able to construct the MAO are willing to punish a PA who decides to keep everything in the post-harvest season, a number comparable to the most punishing societies in the study of Henrich et al. (2006), the Kenyan Gusii and Maragoli tribes. This share drops to 62 percent in the post-harvest season, similar to the average punishment choice frequency for zero transfers in the 15 small-scale societies studied in Henrich et al. (2006) (MWT: $\mathrm{p}<0.01, \mathrm{n}=123$; Columns 1 and 3 in Table 3 ).

Finding 3: Afghan farmers substantially decrease intensity of norm enforcement mechanisms during the lean season.

As in the case of the sharing behavior, the experimental design also allows me to examine punishing behavior across seasons within an individual. There were 52 PCs for whom I could construct the MAO in both rounds. The remaining 19 PCs behaved inconsistently in either of the seasons, but never in both. In the lean season $11 \mathrm{PCs}$ behaved inconsistently compared to 8 PCs in the post-harvest season. Overall, 34 PCs decreased the level of punishment in terms of MAO between the post-harvest and the lean seasons, 5 PCs punished exactly the same across both seasons, and 13 increased the level of punishment. Figure 5 presents a histogram of individual changes in MAO across seasons.

What characteristics explain the behavioral change? Table 6 shows that regressing the difference in MAO between the post-harvest and the lean season on a set of regressors that include participant's age, years of schooling, number of household members, individual income in either of the seasons, or the poverty index in either season does not provide us with any explanation for the observed change in behavior apart from one: individual income in the lean season negatively affects the seasonal change in punishment. However, 
since the average income ranges from around 2000 AFN in the lean season to around $2900 \mathrm{AFN}$ in the post-harvest season, this variable does not capture much of the observed seasonal variance in punishment.

\section{Discussion}

In this section I provide some evidence that the drop in the willingness to punish in the lean season can either be attributed to higher uncertainty about the intentions of others or due to higher wealth inequality present at that period. Also, I show that the drop in punishment is not determined by individual severity of the seasonal shock, but rather by the severity of the aggregate shock on the community-level. This implies that a communal social norm is driving the behavioral change. I also show some evidence that speaks for the generalizability of the observed behavior. Besides that, I rule out several possible caveats such as the role of order effects or the effect of changing marginal utility of wealth across seasons as possible explanations for the behavior observed.

\subsection{Determinants of seasonal changes in norm enforcement}

In Section 4.2 I show that there is a substantial drop in punishment behavior in the lean season compared to the post-harvest season. What factor is driving the difference? Several possible explanations can be put forth:

First, punishment might be perceived as a normal good, demand for which increases with increasing income. Examining the correlation between MAO and individual income (Column 3, Table 5), I actually find an opposite: a small, even if statistically insignificant negative correlation $(\beta=-0.06, \mathrm{p}=0.14)$. This effect may be driven by the fact that the wealthier individuals are in general less likely to engage in altruistic punishment. The nature of the data also allows me to examine the change in income within an individual across seasons. Comparing the MAO for those PCs whose reported income was higher in the post-harvest season compared to the lean season $(n=21)$ and those whose income did not increase in the post-harvest season $(n=31)$, I find that MAO is not significantly statistically different across these groups (MWT: $\mathrm{p}=0.42, \mathrm{n}=52) .{ }^{23}$ Specifically, the change in MAO for those whose income did not increase between the post-harvest and the lean season is equal to -1.74 , while the change in MAO for those whose income increased is -1.14 . Conducting a similar analysis for the seasonal difference in the comprehensive poverty index yields similar results. Importantly, the number of PCs whose poverty index was lower in the lean season compared to the post-harvest season is 10, while for the remaining $42 \mathrm{PCs}$ the poverty index increased. Income effects thus do not plausibly explain the observed drop in sharing norms enforcement in the lean season.

\footnotetext{
${ }^{23}$ The number of observations in this analysis is 52 . This is the number of subjects for whom I was able to construct the MAO in both rounds. The income of 14 PCs remained constant across seasons and for 17 PCs it increased in the lean season compared to the post-harvest season. However, while median income was 2500 AFN higher in the lean season for the group of PCs whose income increased, the median drop in income for the group of PCs whose income decreased in the lean season was $4500 \mathrm{AFN}$.
} 
Second, Grechenig, Nicklisch \& Thöni (2010), Xiao \& Kunreuther (2015), and Bornstein \& Weisel (2010) find that the punishment level drops with rising uncertainty about PA's intentions. It is plausible that increasing uncertainty about the PA's financial situation might cause the lower punishment levels observed in the lean season. In other words, the PC in the lean season cannot differentiate between a selfish and a needy PA, which is the reason why he rather abstains from getting involved in the judgment and possible later regret if he decided to punish a needy individual. This uncertainty is generally higher in the lean season. Not only is income level is generally lower, leaving more people below the subsistence threshold, ${ }^{24}$ it is also much more variable. The GINI coefficient for the entire sample reaches 0.47 in the lean season and drops down to 0.33 in the post-harvest season. ${ }^{25}$ Table 2 (Columns 2 and 4 ) shows that the standard deviation for individual income is significantly higher in the lean season (Variance ratio test: $p<0.01$, $\mathrm{n}=278$ ). Similarly, the standard deviation of the comprehensive poverty index is also significantly higher in the lean period (VR test: $\mathrm{p}<0.01, \mathrm{n}=278$ ). However, the predictive power of a model regressing the seasonal change (both individual and village-average) in willingness to punish on the average village-level variance of the poverty index or of income is very small. ${ }^{26}$ Nevertheless, the small sample size of only ten villages does not allow us to rule out the proposed hypothesis.

Third, increased inequality during periods of scarcity has also been shown to predict the rise of grievances, which is one explanation for the rise in conflicts during scarcity (Hidalgo, Naidu, Nichter \& Richardson, 2010; Hsiang, Burke \& Miguel, 2013). It is possible that increased acceptance of violence in solving problems can be associated with the observed decrease in willingness to punish non-cooperative behavior during the period of scarcity. In my sample I observe an increased number of individuals who were engaged in disputes ${ }^{27}$ during the lean season when compared to the post-harvest season (14.5 percent versus 7.7 percent; MWT, $\mathrm{p}=0.02, \mathrm{n}=414$ ).

Table A4 presents supportive evidence for the role of increased grievances in explaining the drop of punishment. The regressions show a negative correlation between the change in the average village-level share of individuals engaged in a dispute between the lean season and the post-harvest season and the change in MAO between the lean season and the post-harvest season. The first three models use average village level change in MAO as a dependent variable. Despite the small number of observations - ten villagesthe effect is highly significant in all three regression specifications that use different analytic weights. Although significance is lower, models 4 to 6 show effects of similar magnitude using individual level changes in MAO as a dependent variable. A simple back of the envelope calculation, with the average change in the share of individuals

\footnotetext{
${ }^{24}$ NRVA (2008) reports that the food consumption of 48 percent of rural Afghans is below a poverty line during the lean season, compared to 21 percent in the post-harvest season.

${ }^{25}$ It can be argued that the PCs might expect the PAs to overcome the uncertainty about the neediness of PBs by keeping the money from the experiment and sharing it afterwards in person. But none of the participants reported willingness to share the money with anyone outside of his family in a post-experimental survey. Almost 90 percent and over 96 percent of the participants reported that they plan to spend the money from the experiments on food or other household expenses in the lean and the post-harvest season, respectively.

${ }^{26}$ Results are available upon request.

${ }^{27}$ Individuals were asked a question whether they were "engaged in a dispute in the previous four weeks".
} 
engaged in disputes being less than 7 percentage points, suggests that the estimate explains around 30 percent of the observed change in punishing behavior. ${ }^{28}$ It is important to note that this effect cannot be interpreted causally. Despite that, the link between relatively higher engagement in disputes and relatively lower punishment behavior in the lean season on a village level is telling.

The design of the experiment does not allow to separate the second and third explanations. One way or the other, Fehr \& Fischbacher (2004a) have provided strong evidence replicated in numerous experiments that without norm enforcement mechanisms groups gradually dwindle to a non-cooperative equilibrium. Boyd et al. (2003) provide a theoretical model showing that third party punishment helps societies to maintain cooperative equilibria even in larger groups and its absence leads to a collapse of cooperation, as selfish individuals invade the population and their behavior provides them with higher payoffs compared to the payoffs of cooperators. A cross-cultural study shows evidence of positive correlation between altruistic sharing and sharing norm enforcement (Henrich et al., 2006). Thus, regardless of PCs' motivations, the drop in norms enforcement in the lean season increases the likelihood of a drop in sharing.

On the other hand, I do not observe a change in behavior of PAs in the TPPG, which speaks against the claim that sharing deteriorates with the lack of norm enforcement. But prosocial behavior both in Boyd et al.'s theoretical model as well as in Fehr \& Fischbacher's experimental study deteriorates only gradually, as the selfish types start invading the population. My result is consistent with such gradual deterioration of cooperative behavior in the case of prolonged scarcity of resources of which-by playing a one-shot game - I only observe the initial stage and of which Hsiang et al. (2013) (emergence of conflict due to climatic change) or Dirks (1980) (breakdown of cooperation during famines) observe the final stage. Similarly, Gneezy \& Fessler (2012) do not observe a change in behavior of PAs in the ultimatum game from peacetime to wartime played only once in each period, despite the observed increase in punishment behavior during wartime.

Similarly to Wutich (2009) who documents that weakening of social networks is only temporary for the duration of a dry season and returns to original levels with the end of the dry season, Afghan farmers maintain some stabilizing mechanisms that prevent them from plunging into non-prosocial equilibria. However, it seems that they lack mechanisms preventing the collapse of cooperation in times of prolonged scarcity or of unexpected shocks. This might explain the dynamics of collapse of cooperation during famines (Turnbull, 1972; Dirks, 1980; Ravallion, 1997). As my results suggest, the drop in prosocial behavior observed in this literature does not necessarily stem from changes in individual preferences, but rather from weaker social norm enforcement. The aim of the next section is to that the change in altruistic punishment can indeed be attributed to changing social norms, rather than to mere individual preferences responding to changing individual conditions.

\footnotetext{
${ }^{28}$ Conducting a similar analysis on an individual level rather than on a village level does not yield significant estimates.
} 


\subsection{Individual preferences or social norms as determinants of punishment behavior}

Although resorting to punishment in the TPPG is generally understood as an expression of willingness to sustain social norms (Henrich \& Boyd, 2001; Boyd et al., 2003; Fehr \& Fischbacher, 2003; Henrich et al., 2006), the behavior could also be driven by individual other-regarding preferences. Such behavior would be consistent with models of inequality aversion (Fehr \& Schmidt, 1999) or the theory of reciprocity (Falk \& Fischbacher, 2006), in which an unkind act of a PA towards a PB has a negative effect on PC's utility. The act of punishment in such models would have two effects: first by the effect of deterrence preventing PAs to engage in unkind behavior in the first place and second by the moderation of selfish PAs' advantageous inequality by reducing their payoff relative to that of other players.

Understanding this distinction is important. If social norms guided the observed behavior, moral authorities in the society could have their say in affecting individual behavior. On the other hand, individual level interventions would hardly make any change, at least on a short term horizon. The opposite argument can be made if individual preferences were driving the observed behavior. My data speak in favor of the explanation based on social norms:

The regression models including variables representing individual exposure to scarcityincome and the comprehensive poverty index in either season - cannot fully explain the behavioral change in punishment behavior (Table 6). On the other hand, examining the average seasonal change in exposure to scarcity within a village is linked to the change in the TPPG MAO between the lean and the post-harvest season in a way that would support the norms-based explanation: the more severe the shock in the average villagelevel poverty, the larger the drop in MAO. Table A5 summarizes the results both using the average village-level change in MAO as a dependent variable (models 1 to 3 ) as well as the invididual-level change in MAO as a dependent variable (models 4 to 6). ${ }^{29}$ It thus seems more plausible that the observed drop in punishment during the lean season is driven by changes in social norms.

\subsection{Generalizability}

Even though more research needs to be done in understanding whether the presented results can be generalized to other populations, it is important to point out that the results are valid for two very different groups. As shown in Table 1, half of the sample in my experiment are ethnic Tajiks and the other half are ethnic Hazaras, the second and third largest ethnic groups in Afghanistan respectively. While the former are Sunni muslims, the latter are Shia muslims, a minority in Afghanistan.

Tajiks are of Persian origin. They are, after Pashtuns, the second largest ethnic group in Afghanistan with around 32 percent of the population. In the Balkh province where the experiments have been conducted Tajiks are the predominant ethnic group,

\footnotetext{
${ }^{29} \mathrm{~A}$ similar regression explaining seasonal changes in MAO by changes in average village-level income does not yield a significant result, though. Results are available upon request.
} 
with around 44 percent of the population (DHS, 2010). The governor of the province is a Tajik himself. Hazaras, people probably of Mongolian descent, constitute around 9 percent of the population of Afghanistan and around 10 percent of the population of Balkh province (DHS, 2010) $)^{30}$. They have historically been a marginalized group in Afghanistan with very different origins from the other ethnic groups in Afghanistan. ${ }^{31}$ As stated earlier, although the two groups live in close proximity and they share the same language, their villages are fully ethnically segregated and there are very few economic interactions between the two areas.

Table A6 shows that all the main results are valid for both the Tajiks (Columns 1 to 3 ) as well as for the Hazaras (Columns 4 to 6) in my sample. That is, the transfers in both the DG and TPPG remain stable over time, and that the enforcement of sharing norms weakens substantially during the lean season. The results are similar not only qualitatively, but also quantitatively.

\subsection{Potential confounds}

The experiment was conducted over two periods, the lean season first and the postharvest season second. What if the order of the experiments alone influences the results? Two findings refute such a claim.

First, it might be argued that the stability of sharing behavior I observe can be attributed to anchoring one's own behavior in the first, lean season experimental round. For this to be the case, the PAs would have to remember their behavior in the previous experimental round. When asked during the post-harvest round post-experimental survey - in an unincentivised question - about how much they transferred in the DG in the previous round, the PAs guesses were correlated more with the actual transfers in the post-harvest round $(0.61, \mathrm{p}<0.01)$, than with the transfers in the lean season round $(0.48, \mathrm{p}<0.01){ }^{32}$ Moreover, only about 32 percent of the participants (22 out of 68 ) correctly guessed their own transfer in the lean season round. Twelve of these 22 participants decided to choose the same amounts in both rounds. When conducting the same analysis as in Table 4 on a subsample of 46 PAs who did not remember their DG transfers from the previous round correctly, I obtain results that are qualitatively very similar to the results obtained for the full sample of $68 \mathrm{PAs}$, with no statistically significant differences in DG or TPPG transfers across seasons (see Table A7).

Second, to examine the possible role of order effects on punishment behavior, I com-

\footnotetext{
${ }^{30}$ The remaining ethnic groups in Balkh province are Pashtuns (12 percent), Uzbeks (11 percent), Turkmen (9 percent), and Balochis (2 percent). The remaining 12 percent did not report their ethnicity. Source: Demographic and Health Survey Afghanistan (2010). Indian Institute for Health Management Research (IIHMR), available online at https://dhsprogram.com/data/dataset/Afghanistan_Special_2010.cfm.

${ }^{31}$ Hazaras faced social, economic and political discrimination, often resulting in atrocities against members of the group. The massacres of Hazaras in 1880s during the reign of Abdur Rahman Khan, and later in 1994 in Kabul and in 1997 in Mazar-e-Sharif during the reign of the Taliban "irreparably damaged the fabric of the country's national and religious soul" (Rashid, 2001, p. 83). Hazaras were sidelined from mainstream Afghan politics when the 1964 constitution ruled that all state officials have to be Sunni (Hanafi) muslims. Although the new constitution does not continue to discriminate against Hazaras and there are many high ranking Hazara officials in the government, the ethnic division is still present.

${ }^{32} \mathrm{I}$ only asked this question to PAs.
} 
pare the subjects who participated in both seasons and are thus susceptible to being influenced by the order of the experimental rounds to the "virgin" population of farmers participating in one season only - either in the lean season or in the post-harvest season. Reassuringly, the personal characteristics of farmers who participated in both seasons and those who participated in the lean season do not differ (Column 7 of Table A8), but the sample of participants recruited for the first time in the post-harvest period is significantly younger and less educated despite the same sampling procedure (Column 9 of Table A8). Table A9 shows that the punishment behavior of PCs who participated in both periods is not statistically significantly different from the "virgin" subjects in the respective seasons (lean season: $\mathrm{F}(1,182)=0.65, \mathrm{p}=0.42$; post-harvest season: $\mathrm{F}(1,182)$ $=0.56, \mathrm{p}=0.46)$. Also, the difference between the sanctioning behavior of "virgin" PCs in the post-harvest season and in the lean season exhibits a very similar declining pattern as I observe among the participants in both periods in Table $5(\mathrm{~F}(1,182)=6.43, \mathrm{p}=0.01)$.

Another confound that might explain the results presented here is that of seasonal changes in marginal utility of wealth. It is plausible that, due to diminishing marginal utility of wealth, an additional ECU in the experiment has a different value in different seasons. This issue gains importance in the context of dramatic seasonal income fluctuations. As the marginal utility of an additional ECU is highest in the lean season on average, we should expect the participants to put a higher value on their own payoffs in the lean season, ceteris paribus. If that was the case, it would be possible to attribute the observed lower willingness to engage in punishment in the lean season to the diminishing marginal utility of wealth. I provide two arguments against this explanation.

First, it is not plausible that the changing marginal utility of wealth would result in a dramatic decline in punishment behavior, but not in the decline in sharing behavior during the lean season. This would imply a disproportionately lower elasticity of willingness to share with respect to wealth compared to the elasticity of willingness to punish with respect to wealth. Since willingness to share is positively correlated with willingness to punish (Henrich et al., 2006), such a conclusion is unlikely. ${ }^{33}$

Second, as discussed in section 5.1, individual-level changes in income and poverty in general cannot explain the differences in behavior across seasons. It is thus rather inconceivable that changing marginal value of money across seasons is driving the observed behavioral change. ${ }^{34}$

\section{Concluding remarks}

A large fraction of the world's population is repeatedly exposed to periods of resource scarcity. Although there a is common understanding of social responses to extreme scarcities such as famines, when cooperation breaks down, we have much less of understanding of social responses to temporary periods of scarcity, common in many rural societies.

\footnotetext{
${ }^{33} \mathrm{My}$ data on the village level also support a positive correlation between the willingness to share and the willingness to punish. Analysis available upon request.

${ }^{34}$ Similarly, if the participants were concerned about seasonal changes in marginal utility of wealth of their matched partners rather than their own, observation of the differential treatment in the sharing and in the sanctioning conditions would be equally unlikely.
} 
In this paper I ask whether a society exposed to seasonal scarcity is able to sustain its informal sharing mechanisms. Specifically, I experimentally examine the dynamics of individual sharing behavior using a dictator game, and of willingness of third parties to engage in enforcement of sharing norms, using a third party punishment game among Afghan subsistence farmers. I visited the area two times in a year-during the lean season and six months later during a post-harvest season, the period of relative plenty - and conducted the same experiment repeatedly with the same participants.

Although the sharing behavior measured by the dictators' transfers in a standard dictator game remains stable over time on both the aggregate level as well as, to a large extent, on the individual level, the enforcement mechanisms that help to sustain the cooperative outcomes - as measured by the intensity of third parties' willingness to punish non-desirable behavior - are significantly weakened during the period of scarcity. ${ }^{35}$ Even though the population studied seems to have developed some mechanisms to sustain prosociality over the period of temporary resource scarcities during the lean season, it is not implausible that cooperation might deteriorate if the population experiences a larger shock or if it is exposed to scarcity over a longer period of time than expected. This would be consistent with the decline in cooperation over time when enforcement mechanisms are not available, observed in previous laboratory experiments (Boyd et al., 2003; Fehr \& Fischbacher, 2004a).

It is not clear how narrow this gap between cooperation and its breakdown is and more research should be done in this direction, but the present study offers some evidence that even temporary periods of resource scarcity substantially weaken the enforcement of sharing norms. Policy makers should take this finding seriously in addressing the issue of transitory scarcity, not only as a problem at the individual level, but also at the community level. More importantly, as mounting evidence on causal links between resource scarcity and emergence of conflicts on a community level shows (Hsiang et al., 2013) it is possible that many societies exposed to temporary periods of resource scarcity might be closer to a spark of violence than was previously thought. The herein observed erosion of social norm enforcement might be one of the explanatory factors. ${ }^{36}$

Policymakers already offer solutions to mitigate the seasonal scarcities and scarcities in general via the introduction of safety net programs (Alderman \& Yemtsov, 2014), provision of formal insurance (Morduch, 2006), or provision of microcredit (Banerjee, 2013). While they usually promote the impact of these policies on individuals, they often fall short of stressing their possible effect on preventing negative outcomes on the community level. Moreover, since scarcity is shown here to be associated with looser social norms enforcement, concerns that introduction of such policies would crowd out existing informal institutions seem less plausible.

\footnotetext{
${ }^{35}$ Since sharing preferences are predictive of trusting and cooperative behavior, the results might have important implications for the functioning of markets and the ability of communities to mobilize and engage in collective action during periods of scarcity.

${ }^{36}$ See for example Sekhri \& Storeygard (2013) or Blakeslee \& Fishman (2013) who document an increase in violence and property crime as a response to rainfall failure in India or Oster, 2004 and Miguel, 2005 who document increased incidence of ritual murders after rainfall failures in renaissance Europe and in current rural Tanzania.
} 


\section{References}

Alderman, H. \& Yemtsov, R. (2014). How can safety nets contribute to economic growth? World Bank Economic Review, 28(1), 1-20.

Almås, I., Cappelen, A. W., Sørensen, E. Ø., \& Tungodden, B. (2010). Fairness and the Development of Inequality Acceptance. Science, 328(5982), 1176-1178.

Andersen, S., Harrison, G. W., Lau, M. I., \& Elisabet Rutström, E. (2008). Lost in state space: Are preferences stable? International Economic Review, 49(3), 1091-1112.

Andreoni, J. \& Miller, J. (2002). Giving according to GARP: An experimental test of the consistency of preferences for altruism. Econometrica, $70(2), 737-753$.

Attanasio, O., Barr, A., Cardenas, J. C., Genicot, G., \& Meghir, C. (2012). Risk Pooling, Risk Preferences, and Social Networks. American Economic Journal: Applied Economics, 4(2), 134-167.

Banerjee, A. V. (2013). Microcredit Under the Microscope: What Have We Learned in the Past Two Decades, and What Do We Need to Know? Annual Review of Economics, 5(1), 487-519.

Barr, A. \& Genicot, G. (2008). Risk Sharing, Commitment, and Information: An Experimental Analysis. Journal of the European Economic Association, 6(6), 1151-1185.

Basu, K. \& Wong, M. (2015). Evaluating seasonal food storage and credit programs in east Indonesia. Journal of Development Economics, 115, 200-216.

Bauer, M., Cassar, A., Chytilová, J., \& Henrich, J. (2014). Wars Enduring Effects on the Development of Egalitarian Motivations and In-Group Biases. Psychological Science, $25(1), 47-57$.

Bernhard, H., Fischbacher, U., \& Fehr, E. (2006). Parochial altruism in humans. Nature, 442(7105), 912-915.

Blakeslee, D. \& Fishman, R. (2013). Rainfall shocks and property crimes in agrarian societies: Evidence from India.

Block, J. (1983). Lives Through Time. Berkeley, CA: Bancroft Books.

Bornstein, G. \& Weisel, O. (2010). Punishment, cooperation, and cheater detection in noisy social exchange. Games, 1(1), 18-33.

Boyd, R., Gintis, H., Bowles, S., \& Richerson, P. J. (2003). The evolution of altruistic punishment. Proceedings of the National Academy of Sciences of the United States of America, 100(6), 3531-3535.

Bryan, G., Chowdhury, S., \& Mobarak, A. M. (2014). Under-investment in a Profitable Technology : The Case of Seasonal Migration in Bangladesh. Econometrica, 82(5), 1671-1748. 
Camerer, C. F. (2003). Behavioral Game Theory: Experiments in Strategic Interaction. Princeton, NJ: Princeton University Press.

Cameron, L. \& Shah, M. (2015). Risk-Taking Behavior in the Wake of Natural Disasters. Journal of Human Resources, 50(2), 484-515.

Choi, J.-K. \& Bowles, S. (2007). The Coevolution of Parochial Altruism and War. Science, 318(5850), 636-640.

Cohen, S., Kamarck, T., \& Mermelstein, R. (1983). A Global Measure of Perceived Stress. Journal of Health and Social Behavior, 24(4), 385-396.

Collins, D., Morduch, J., Rutherford, S., \& Ruthven, O. (2009). Portfolios of the poor: how the world's poor live on $\$ 2$ a day. Princeton, NJ: Princeton University Press.

Cronk, L., Chagnon, N. A., \& Irons, W. (Eds.). (2000). Adaptation and human behavior: an anthropological perspective. Piscataway, NJ: Transaction Publishers.

DellaVigna, S., List, J. A., \& Malmendier, U. (2012). Testing for altruism and social pressure in charitable giving. Quarterly Journal of Economics, 127(1), 1-56.

Devereux, S., Swan, S. H., \& Vaitla, B. (2008). Seasons of Hunger: Fighting Cycles of Starvations Among the World's Rural Poor. London, UK: Pluto Press.

Dirks, R. (1980). Social Responses During Severe Food Shortages and Famine. Current Anthropology, 21(1), 21-32.

Engel, C. (2011). Dictator games: a meta study. Experimental Economics, 14(4), 583610.

Evans-Pritchard, E. E. (1969). The Nuer: A Description of the Modes of Livelihood and Political Institutions of a Nilotic People. Oxford, UK: Oxford University Press.

Falk, A. \& Fischbacher, U. (2006). A theory of reciprocity. Games and Economic Behavior, 54 (2), 293-315.

FAO (2012). FAO statistical yearbook 2012: World food and agriculture. Technical report, Food and Agriculture Organization of the United Nations, Rome, Italy.

Fehr, E., Bernhard, H., \& Rockenbach, B. (2008). Egalitarianism in young children. Nature, 454(7208), 1079-1083.

Fehr, E. \& Fischbacher, U. (2003). The nature of human altruism. Nature, 425(6960), $785-791$.

Fehr, E. \& Fischbacher, U. (2004a). Social norms and human cooperation. Trends in cognitive sciences, 8(4), 185-190.

Fehr, E. \& Fischbacher, U. (2004b). Third-party punishment and social norms. Evolution and Human Behavior, 25(2), 63-87. 
Fehr, E. \& Gächter, S. (2000). Cooperation and Punishment in Public Goods Experiments. American Economic Review, 90(4), 980-994.

Fehr, E. \& Schmidt, K. M. (1999). A Theory of Fairness, Competition, and Cooperation. The Quarterly Journal of Economics, 114(3), 817-868.

Fessler, D. M. \& Navarrete, C. D. (2004). Third-party attitudes toward sibling incest: Evidence for Westermarck's hypotheses. Evolution and Human Behavior, 25(5), 277294.

Fisman, R., Jakiela, P., \& Kariv, S. (2015). How did distributional preferences change during the Great Recession? Journal of Public Economics, 128, 84-95.

Gintis, H. (2000). Strong Reciprocity and Human Sociality. Journal of Theoretical Biology, 206, 169-179.

Gneezy, A. \& Fessler, D. M. T. (2012). Conflict, sticks and carrots: war increases prosocial punishments and rewards. Proceedings. Biological sciences / The Royal Society, 279(1727), 219-223.

Grechenig, K., Nicklisch, A., \& Thöni, C. (2010). Punishment despite reasonable doubt - a public goods experiment with sanctions under uncertainty. Journal of Empirical Legal Studies, 7(4), 847-867.

Greif, A. (1993). Contract Enforceability and Economic Institutions in Early Trade: The Maghribi Traders' Coalition. American Economic Review, 83(3), 525-548.

Grossman, H. I. \& Mendoza, J. (2003). Scarcity and appropriative competition. European Journal of Political Economy, 19(4), 747-758.

Gürerk, O., Irlenbusch, B., \& Rockenbach, B. (2006). The competitive advantage of sanctioning institutions. Science, 312(5770), 108-11.

Henrich, J. \& Boyd, R. (2001). Why people punish defectors. Weak conformist transmission can stabilize costly enforcement of norms in cooperative dilemmas. Journal of Theoretical Biology, 208, 79-89.

Henrich, J., Ensminger, J., McElreath, R., Barr, A., Barrett, C., Bolyanatz, A., Cardenas, J. C., Gurven, M., Gwako, E., Henrich, N., Lesorogol, C., Marlowe, F., Tracer, D., \& Ziker, J. (2010). Markets, religion, community size, and the evolution of fairness and punishment. Science, 327(5972), 1480-4.

Henrich, J., McElreath, R., Barr, A., Ensminger, J., Barrett, C., Bolyanatz, A., Cardenas, J. C., Gurven, M., Gwako, E., Henrich, N., Lesorogol, C., Marlowe, F., Tracer, D., \& Ziker, J. (2006). Costly Punishment Across Human Societies. Science, 312(5781), 1767-70.

Hidalgo, F. D., Naidu, S., Nichter, S., \& Richardson, N. (2010). Economic determinants of land invasions. Review of Economics and Statistics, 92(3), 505-523. 
Hsiang, S. M., Burke, M., \& Miguel, E. (2013). Quantifying the Influence of Climate on Human Conflict. Science, 341(6151), 1235367-1-1235367-14.

Jalan, J. \& Ravallion, M. (1999). Are the poor less well insured? Evidence on vulnerability to income risk in rural China. Journal of Development Economics, 58(1), $61-81$.

Jessor, R. (1983). The Stability of Change: Psychosocial Development From Adolescence to Young Adulthood. In D. Magnusson \& V. L. Allen (Eds.), Human Development: An Interactional Perspective. New York, NY: Academic Press.

Kahneman, D., Knetsch, J. L., \& Thaler, R. H. (1986). Fairness as a constraint on profit seeking: Entitlements in the market. American Economic Review, 76(4), 728-741.

Khandker, S. R. \& Mahmud, W. (2012). Seasonal hunger and public policies: evidence from Northwest Bangladesh. Washington, DC: World Bank Publications.

Leider, S., Mobius, M. M., Rosenblat, T., \& Do, Q.-A. (2009). Directed Altruism and Enforced Reciprocity in Social Networks. Quarterly Journal of Economics, 124(4), $1815-1851$.

Lévesque, C., de Juriew, D., Lussier, C., \& Trudeau, N. (2000). Between abundance and scarcity: food and the institution of sharing among the Inuit of the Circumpolar region during the recent historical period. In D. Gerard (Ed.), Sustainable Development in the Arctic Conditions of Food Security chapter 6, (pp. 103-115). Montreal.

Ligon, E. \& Schechter, L. (2012). Motives for sharing in social networks. Journal of Development Economics, 99(1), 13-26.

List, J. A., Berrens, R. P., Bohara, A. K., \& Kerkvliet, J. (2004). Examining the role of social isolation on stated preferences. American Economic Review, 94(3), 741-752.

Maldonado, J. H., Moreno-Sánchez, R. d. P., \& del Pilar, R. (2009). Does Scarcity Exacerbate the Tragedy of the Commons?: Evidence from Fishers' Experimental Responses.

Mani, A., Mullainathan, S., Shafir, E., \& Zhao, J. (2013). Poverty Impedes Cognitive Function. Science, 341(6149), 976-980.

Meier, S. \& Sprenger, C. D. (2015). Temporal stability of time preferences. Review of Economics and Statistics, 97(2), 273-286.

Miguel, E. (2005). Poverty and Witch Killing. Review of Economic Studies, 72(4), $1153-1172$.

Morduch, J. (1995). Income smoothing and consumption smoothing. The Journal of Economic Perspectives, 9(3), 103-114. 
Morduch, J. (2006). Micro-insurance: the next revolution? In A. Banerjee, R. Benabou, \& D. Mookherjee (Eds.), What Have We Learned About Poverty? (pp. 337-356). Oxford University Press.

NRVA (2008). National Risk and Vulnerability Assessment 2007/8. Technical report, Ministry of Rehabilitation and Rural Development and the Central Statistics Organisation (CSO), Kabul, Afghanistan.

Osés-Eraso, N. \& Viladrich-Grau, M. (2007). Appropriation and concern for resource scarcity in the commons: An experimental study. Ecological Economics, 63(2-3), $435-445$.

Oster, E. (2004). Witchcraft, Weather and Economic Growth in Renaissance Europe. Journal of Economic Perspectives, 18(1), 215-228.

Ostrom, E., Burger, J., Field, C. B., Norgaard, R. B., \& Policansky, D. (1999). Revisiting the Commons: Local Lessons, Global Challenges. Science, 284(5412), 278-282.

Prediger, S., Vollan, B., \& Herrmann, B. (2014). Scarcity and Antisocial Behavior. Journal of Public Economics, 119, 1-9.

Rashid, A. (2001). Taliban - Militant Islam, Oil $\&$ Fundamentalism in Central Asia. New Haven, CT: Yale University Press.

Ravallion, M. (1997). Famines and economics. Journal of Economic Literature, 35(3), $1205-1242$.

Sahn, D. E. (1989). Seasonal Variability in Third World Agriculture. Baltimore, MD: The International Food Policy Research Institute.

Sekhri, S. \& Storeygard, A. (2013). Dowry deaths: Consumption smoothing in response to climate variability in India. Unpublished Manuscript.

Townsend, R. M. (1994). Risk and insurance in village India. Econometrica, 62(3), $539-591$.

Turnbull, C. M. (1972). The Mountain People. New York, NY: Touchstone.

Varghese, S. K., Veettil, P. C., Speelman, S., Buysse, J., \& Van Huylenbroeck, G. (2013). Estimating the causal effect of water scarcity on the groundwater use efficiency of rice farming in South India. Ecological Economics, 86, 55-64.

Volk, S., Thöni, C., \& Ruigrok, W. (2012). Temporal stability and psychological foundations of cooperation preferences. Journal of Economic Behavior 85 Organization, $81(2), 664-676$.

Voors, M. J., Nillesen, E. E. M., Bulte, E. H., Lensink, B. W., Verwimp, P., \& Soest, D. P. V. (2012). Violent Conflict and Behavior : a Field Experiment in Burundi. American Economic Review, 102(2), 941-64. 
Wutich, A. (2009). Water Scarcity and the Sustainability of a Common Pool Resource Institution in the Urban Andes. Human Ecology, 37(2), 179-192.

Xiao, E. \& Kunreuther, H. (2015). Punishment and cooperation in stochastic social dilemmas. Journal of Conflict Resolution. 
Figure 1: Subjective perceptions of living quality throughout the year

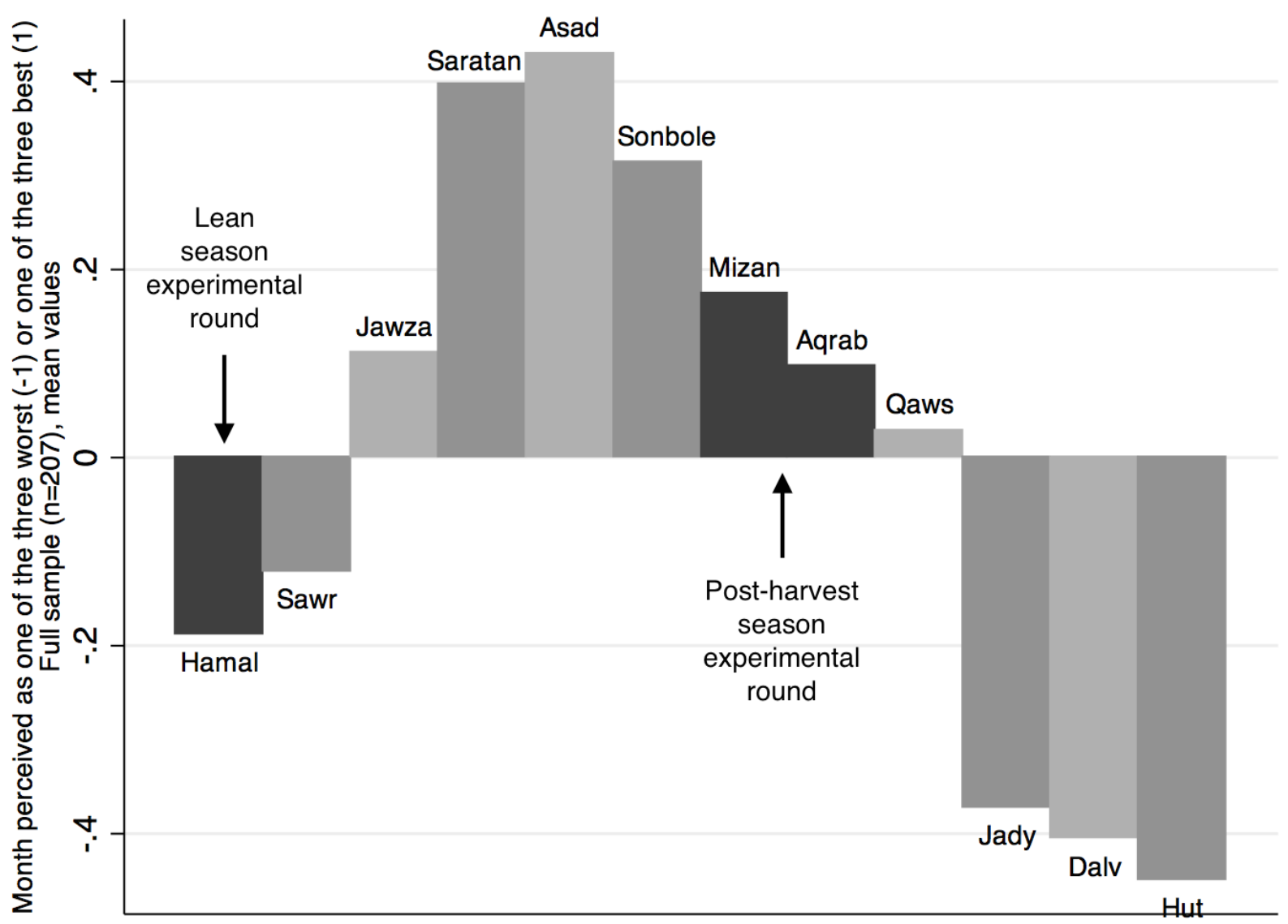

Notes: The figure depicts the average participants' rating of quality of life during the particular month. The participants rated the month as one of the best thee months $(+1)$ or as one of the worst three months in a question "Which three months are usually the [best /most difficult] in terms of food for you?". Months not mentioned are treated as 0. The question was asked during the lean season round. Afghanistan uses the Persian version of the Solar Hijri calendar. Persian month names are presented here. The experiments were carried out in the months of Hamal 1392 (March to April 2013, lean season) and Mizan and Aqrab 1392 (October 2013, post-harvest season) represented in the darkest color. 
Figure 2: Cumulative distributions of DG and TPPG transfers across seasons
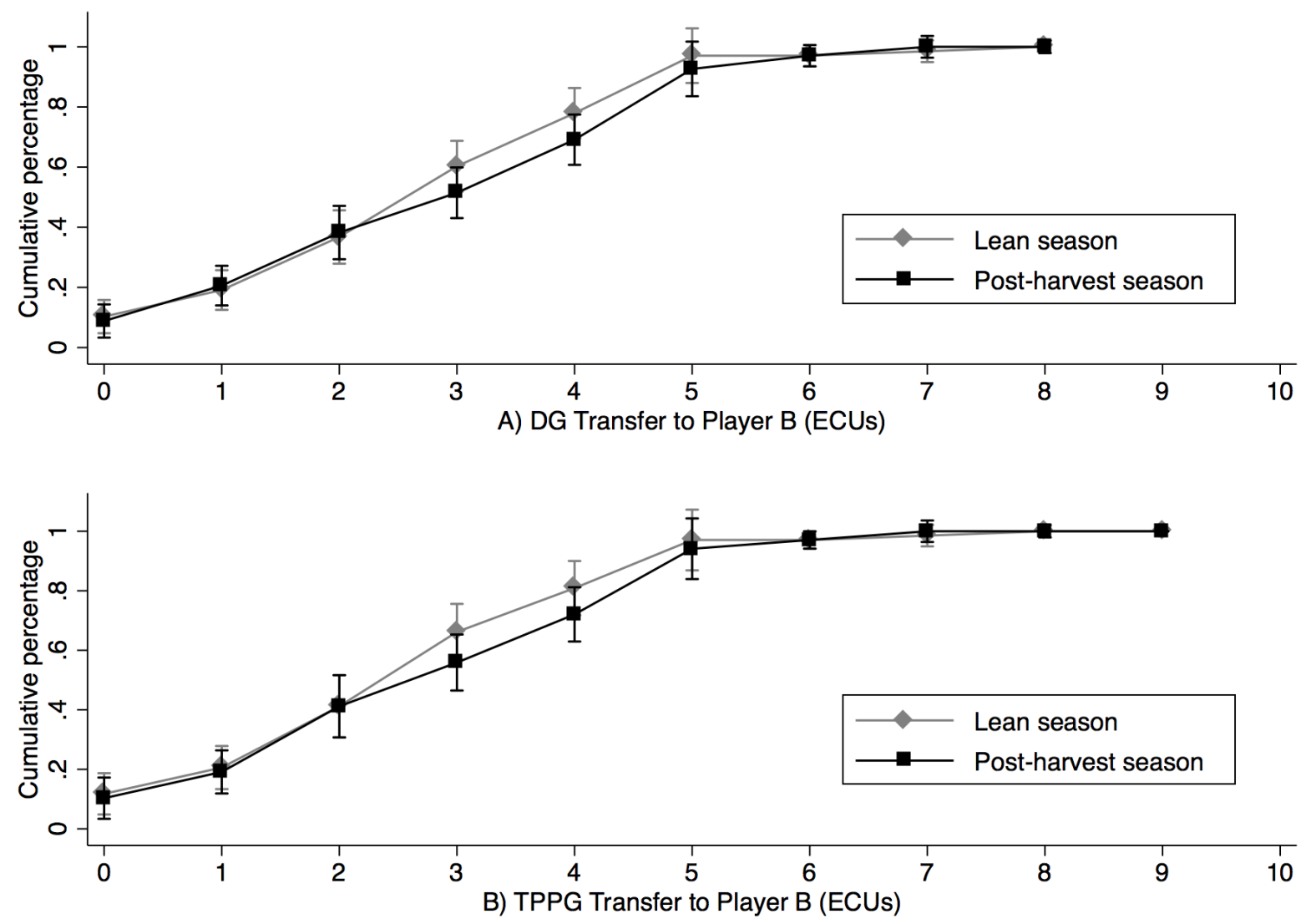

Notes: The figure shows the cumulative distribution of transfers from Player A (dictator) to Player $\mathrm{B}$ (passive receiver) in ECUs (allowed between 0 and 10) in A) the dictator game (DG) and B) the third party punishment game (TPPG) across the PAs participating in both rounds $(n=68)$. The cumulative distribution of lean season transfers is depicted in grey, the cumulative distribution of post-harvest season transfers is depicted in black. The error bars represent 95 percent confidence intervals. 
Figure 3: Distributions of individual changes in DG and TPPG transfers across seasons
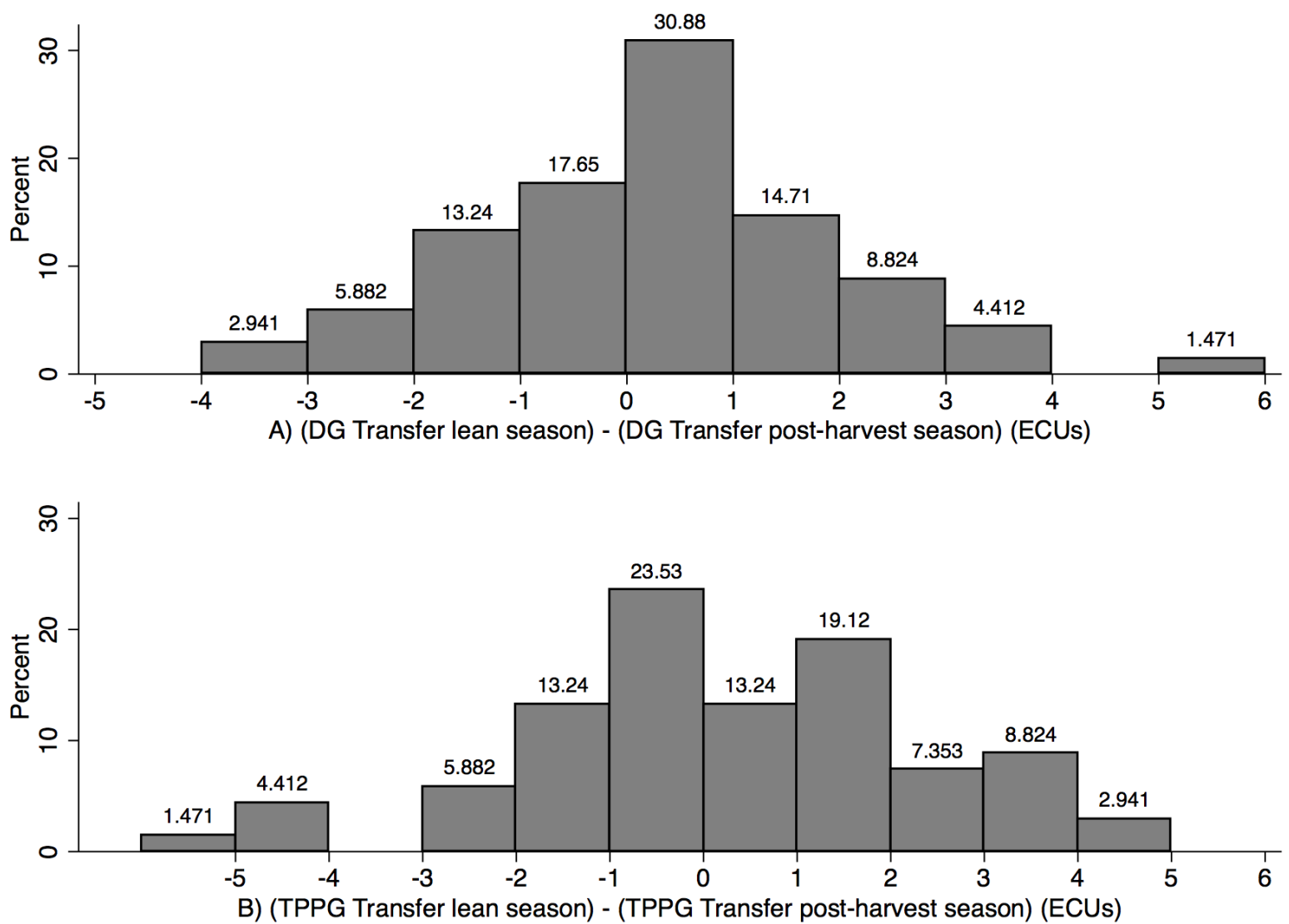

Notes: The figure shows the distributions of differences between the transfers in the lean season and the post-harvest season in A) the DG and B) the TPPG within a participant. Transfer differences are in ECUs (the possible range is from -10 to 10 ). 
Figure 4: Distributions of TPPG MAO across seasons

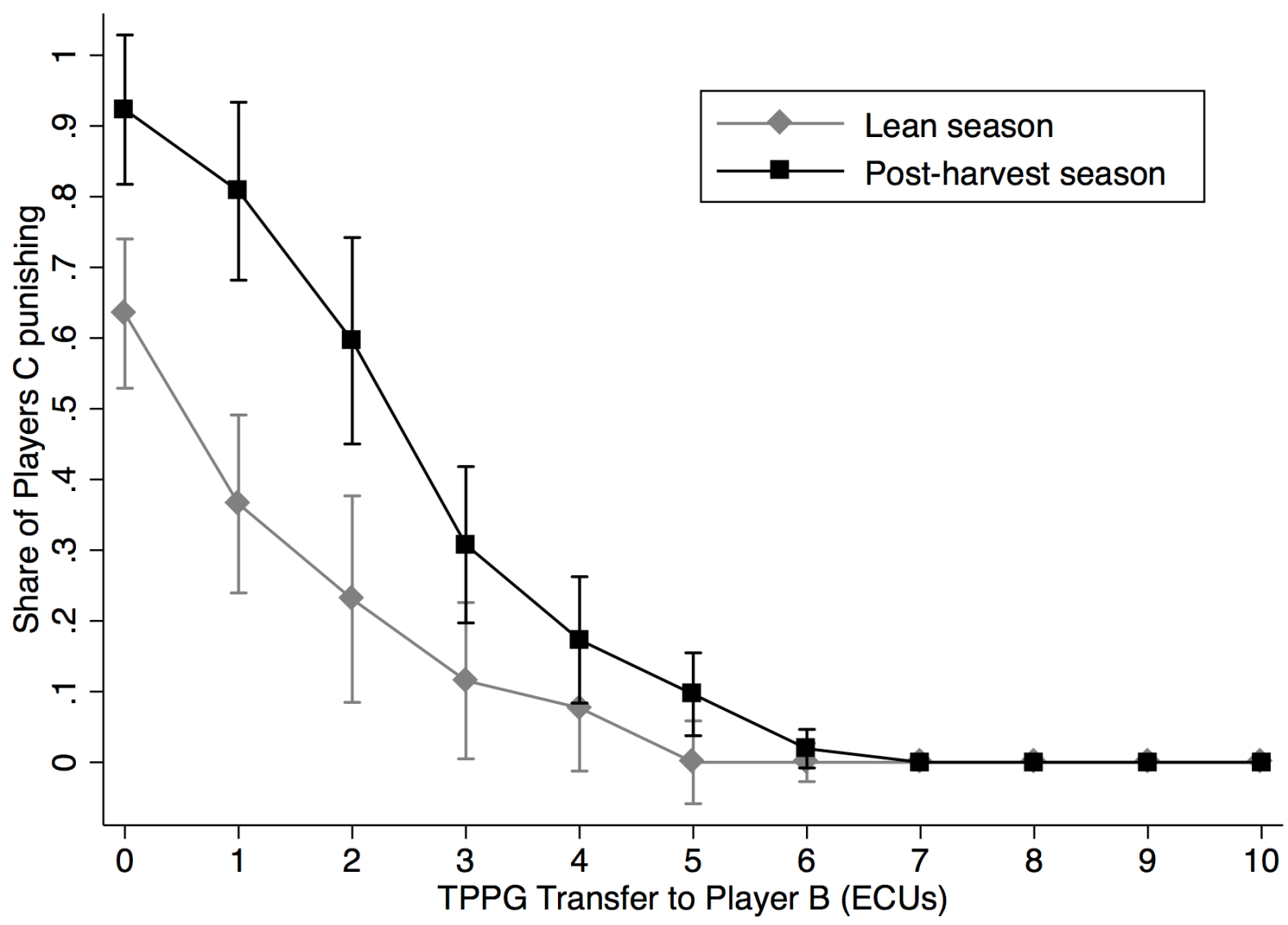

Notes: The figure shows the distribution of Player Cs' (punishers) minimum acceptable Player As' offers to Player B in the third party punishment game (TPPG MAO). I use data for the 52 PCs for whom MAO could be recovered in both rounds. The distribution of lean season MAO is depicted in grey, the distribution of post-harvest season MAO is depicted in black. The error bars represent 95 percent confidence intervals. 
Figure 5: Distributions of individual changes in TPPG MAO across seasons

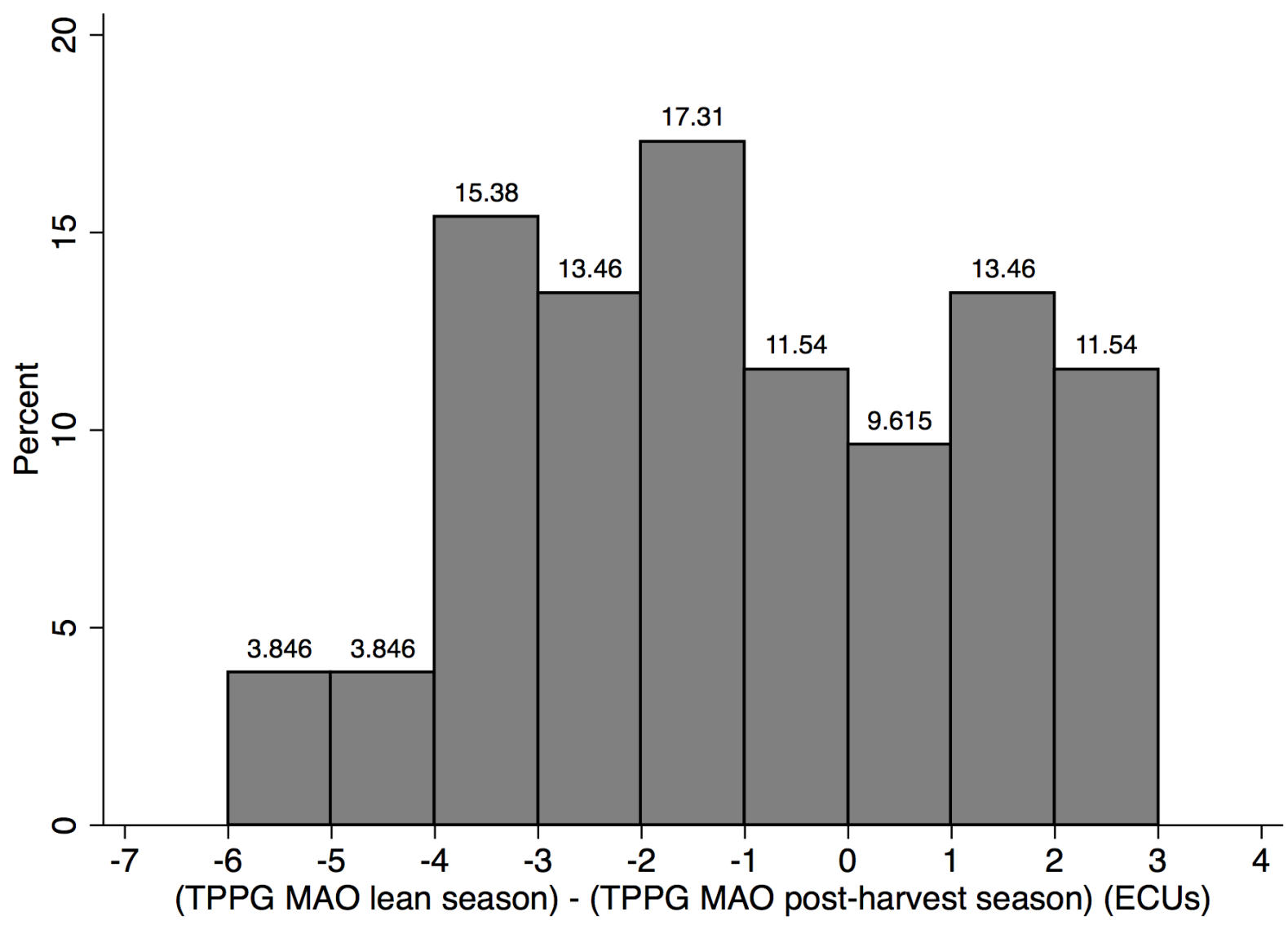

Notes: The figure shows the distribution of within-individual changes in Player Cs' (punishers) minimum acceptable Player As' offers to Player B in the third party punishment game (TPPG $\mathrm{MAO}$ ) between the lean and the post-harvest season. I use data for the $52 \mathrm{PCs}$ for whom MAO could be recovered in both rounds. Positive numbers represent higher MAO in the post-harvest season compared to the lean season. 
Table 1: Descriptive statistics

\begin{tabular}{lcc}
\hline & Mean & SD \\
& $(1)$ & $(2)$ \\
\cline { 2 - 3 } Age & 38.83 & $(15.49)$ \\
Schooling (completed years) & 2.97 & $(3.82)$ \\
Can read letter (d) & 0.58 & $(0.49)$ \\
Number of household members & 9.66 & $(4.69)$ \\
Household head (d) & 0.83 & $(0.38)$ \\
Not married (d) & 0.11 & $(0.32)$ \\
Married to a single wife (d) & 0.71 & $(0.45)$ \\
Married to multiple wives (d) & 0.18 & $(0.38)$ \\
Daughters below 15 & 1.93 & $(1.66)$ \\
Sons below 15 & 2.13 & $(1.60)$ \\
Years living in village & 36.98 & $(16.59)$ \\
Sunni (d) & 0.51 & $(0.50)$ \\
Irrigated land (in jiribs) & 4.47 & $(7.36)$ \\
Rainfed land (in jiribs) & 10.81 & $(18.68)$ \\
Observations & \multicolumn{2}{c}{207} \\
\hline
\end{tabular}

Notes: Means of the sample participating in both seasons are reported. Standard deviations in parentheses. ${ }^{a}$ These questions were only asked to a subsample of players A and C $(\mathrm{N}=194)$. 

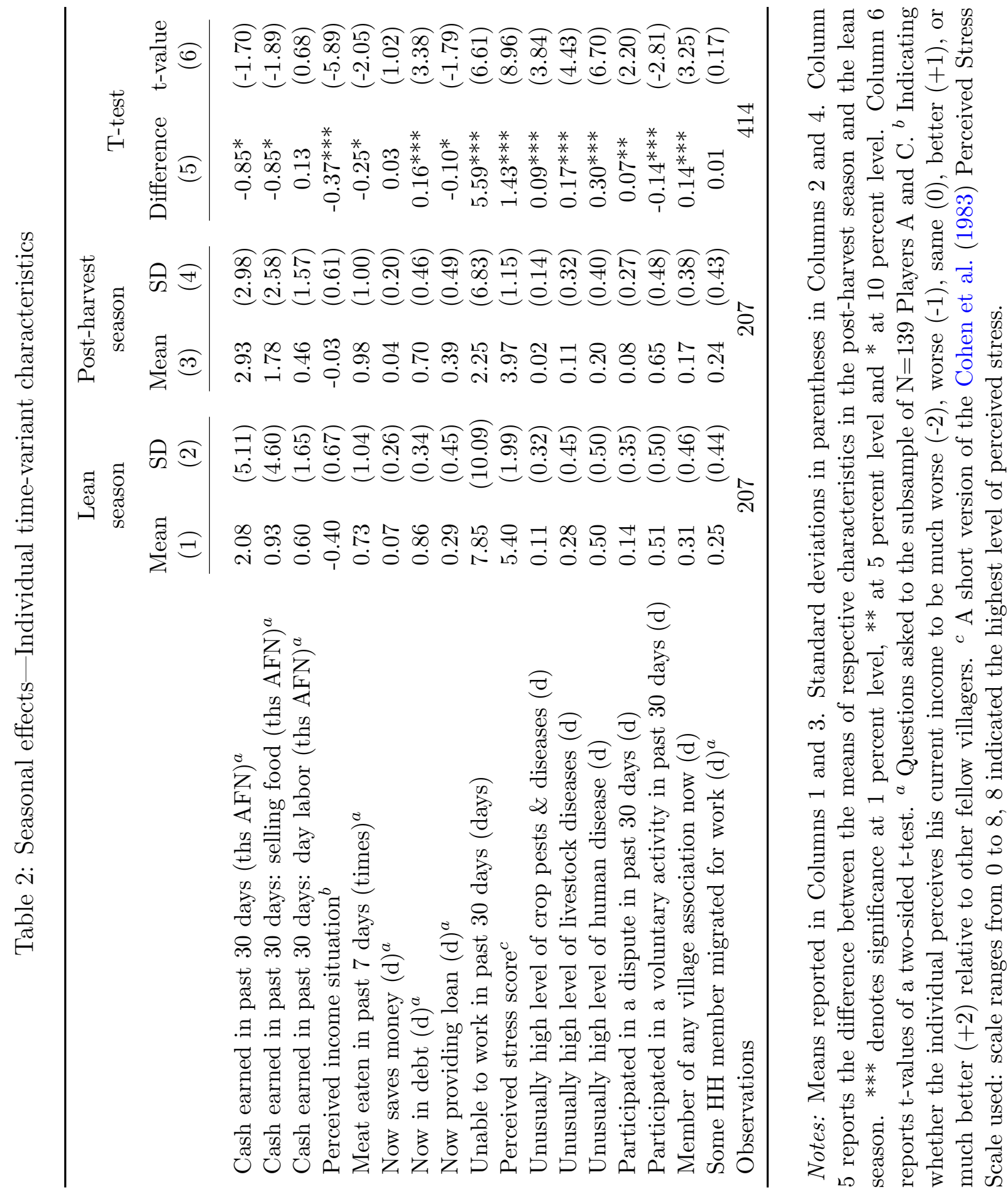


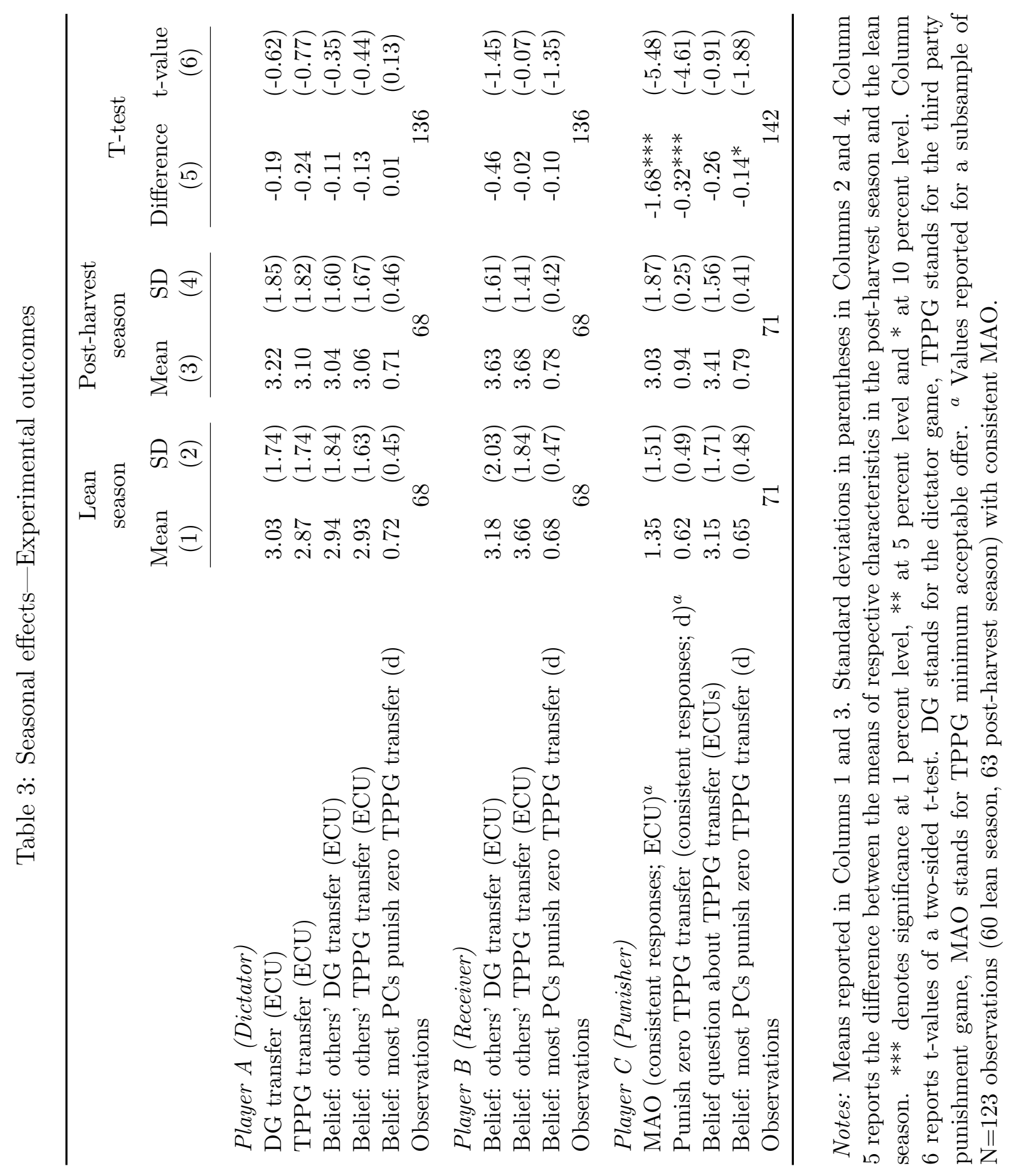




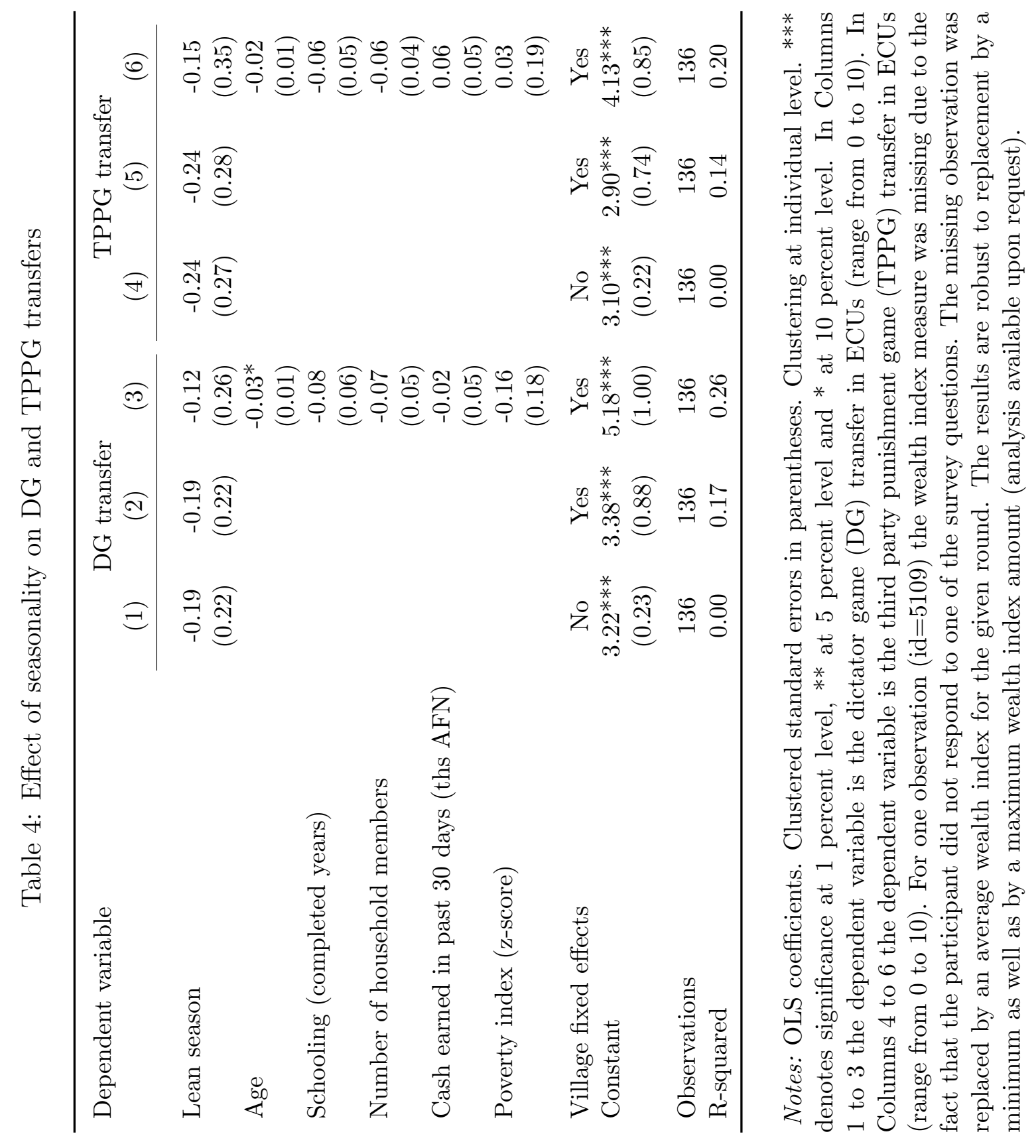


Table 5: Effect of seasonality on TPPG MAO

\begin{tabular}{|c|c|c|c|}
\hline Dependent variable & \multicolumn{3}{|c|}{$\begin{array}{l}\text { TPPG Minimum Acceptable Offer } \\
\begin{array}{l}\text { (1) } \\
\text { (2) }\end{array}\end{array}$} \\
\hline Lean season & $\begin{array}{c}-1.68^{* * *} \\
(0.31)\end{array}$ & $\begin{array}{c}-1.68^{* * *} \\
(0.32)\end{array}$ & $\begin{array}{c}-1.49^{* * *} \\
(0.35)\end{array}$ \\
\hline Age & & & $\begin{array}{l}-0.02^{*} \\
(0.01)\end{array}$ \\
\hline Schooling (completed years) & & & $\begin{array}{c}0.02 \\
(0.06)\end{array}$ \\
\hline Number of household members & & & $\begin{array}{l}-0.04 \\
(0.04)\end{array}$ \\
\hline Cash earned in past 30 days (ths AFN) & & & $\begin{array}{l}-0.06 \\
(0.04)\end{array}$ \\
\hline Poverty index (z-score) & & & $\begin{array}{l}-0.23 \\
(0.14)\end{array}$ \\
\hline Village fixed effects & No & Yes & Yes \\
\hline Constant & $\begin{array}{c}3.03^{* * *} \\
(0.24)\end{array}$ & $\begin{array}{c}3.43^{* * *} \\
(0.54)\end{array}$ & $\begin{array}{c}4.52^{* * *} \\
(0.95)\end{array}$ \\
\hline Observations & 123 & 123 & 123 \\
\hline R-squared & 0.20 & 0.27 & 0.34 \\
\hline
\end{tabular}

Notes: OLS coefficients. Clustered standard errors in parentheses. Clustering at individual level. ${ }^{* * *}$ denotes significance at 1 percent level, ${ }^{* *}$ at 5 percent level and ${ }^{*}$ at 10 percent level. The dependent variable in all models is the third party punishment game (TPPG) minimum acceptable offer (MAO). Subsample of $\mathrm{N}=123$ observations (60 lean season, 63 post-harvest season) with consistent MAO. 
Table 6: Explaining within-individual changes in MAO across seasons

\begin{tabular}{|c|c|c|c|}
\hline Dependent variable & TPPG & MAO Di & Ference \\
\hline & $(1)$ & $(2)$ & $(3)$ \\
\hline Age & 0.01 & 0.01 & -0.00 \\
\hline & $(0.03)$ & $(0.03)$ & $(0.03)$ \\
\hline Schooling (completed year) & 0.15 & 0.11 & 0.09 \\
\hline & $(0.10)$ & $(0.09)$ & $(0.11)$ \\
\hline Number of household members & 0.05 & 0.05 & -0.02 \\
\hline & $(0.11)$ & $(0.10)$ & $(0.10)$ \\
\hline Cash earned in past 30 days (ths AFN) - Lean season & $-0.09^{* *}$ & $-0.08^{*}$ & \\
\hline & $(0.05)$ & $(0.05)$ & \\
\hline Cash earned in past 30 days (ths AFN) - Post-harvest season & 0.20 & & 0.13 \\
\hline & $(0.22)$ & & $(0.22)$ \\
\hline Poverty index (z-score) - Lean season & -0.28 & -0.24 & \\
\hline & $(0.33)$ & $(0.31)$ & \\
\hline Poverty index (z-score) - Post-harvest season & 0.41 & & 0.24 \\
\hline & $(0.55)$ & & $(0.54)$ \\
\hline Village fixed effects & Yes & Yes & Yes \\
\hline Constant & $-3.59^{* *}$ & -2.83 & -2.52 \\
\hline & $(1.72)$ & $(1.69)$ & $(1.71)$ \\
\hline Observations & 52 & 52 & 52 \\
\hline R-squared & 0.27 & 0.24 & 0.22 \\
\hline
\end{tabular}

Notes: OLS coefficients. Robust standard errors in parentheses. ${ }^{* * *}$ denotes significance at 1 percent level, ${ }^{* *}$ at 5 percent level and ${ }^{*}$ at 10 percent level. The dependent variable in all models is the within-subject third party punishment game (TPPG) minimum acceptable offer (MAO) difference between MAO in the lean season and MAO in the post-harvest season. I control for village fixed effects in all models. Subsample of $\mathrm{N}=52$ observations in each season with MAO consistent in both seasons. 


\section{A Supplementary online materials}

Table A1: Village level effects

\begin{tabular}{|c|c|c|c|c|c|c|}
\hline \multirow[t]{2}{*}{ Dependent variable } & \multicolumn{3}{|c|}{ DG transfer } & \multicolumn{3}{|c|}{ TPPG transfer } \\
\hline & $\begin{array}{l}\text { Full } \\
(1)\end{array}$ & $\begin{array}{l}\text { Lean } \\
(2)\end{array}$ & $\begin{array}{c}\text { Post-harvest } \\
\text { (3) }\end{array}$ & $\begin{array}{l}\text { Full } \\
(4)\end{array}$ & $\begin{array}{l}\text { Lean } \\
(5)\end{array}$ & $\begin{array}{c}\text { Post-harvest } \\
\text { (6) }\end{array}$ \\
\hline Marghzar & $\begin{array}{c}0.40 \\
(0.78)\end{array}$ & $\begin{array}{c}1.11 \\
(1.20)\end{array}$ & $\begin{array}{l}-0.30 \\
(1.06)\end{array}$ & $\begin{array}{c}0.59 \\
(0.76)\end{array}$ & $\begin{array}{c}1.43 \\
(1.22)\end{array}$ & $\begin{array}{l}-0.25 \\
(0.95)\end{array}$ \\
\hline Koche Aghaz & $\begin{array}{c}-1.32^{*} \\
(0.71)\end{array}$ & $\begin{array}{l}-1.36 \\
(1.14)\end{array}$ & $\begin{array}{l}-1.29 \\
(0.93)\end{array}$ & $\begin{array}{l}-0.64 \\
(0.71)\end{array}$ & $\begin{array}{l}-0.71 \\
(1.13)\end{array}$ & $\begin{array}{l}-0.57 \\
(0.94)\end{array}$ \\
\hline Jaw-Paya Ali Abad & $\begin{array}{l}-0.29 \\
(0.77)\end{array}$ & $\begin{array}{l}-0.39 \\
(1.15)\end{array}$ & $\begin{array}{l}-0.18 \\
(1.10)\end{array}$ & $\begin{array}{c}0.34 \\
(0.86)\end{array}$ & $\begin{array}{l}-0.82 \\
(1.20)\end{array}$ & $\begin{array}{l}1.50^{*} \\
(0.80)\end{array}$ \\
\hline Baizai Bala & $\begin{array}{c}0.40 \\
(0.77)\end{array}$ & $\begin{array}{c}0.36 \\
(1.14)\end{array}$ & $\begin{array}{c}0.45 \\
(1.11)\end{array}$ & $\begin{array}{c}0.90 \\
(0.73)\end{array}$ & $\begin{array}{c}1.05 \\
(1.11)\end{array}$ & $\begin{array}{l}0.75 \\
(1.04)\end{array}$ \\
\hline Abpartob & $\begin{array}{c}1.21 \\
(0.81)\end{array}$ & $\begin{array}{c}1.19 \\
(1.21)\end{array}$ & $\begin{array}{c}1.24 \\
(1.15)\end{array}$ & $\begin{array}{l}1.55^{*} \\
(0.85)\end{array}$ & $\begin{array}{c}1.76 \\
(1.20)\end{array}$ & $\begin{array}{c}1.33 \\
(1.31)\end{array}$ \\
\hline Kheirabad & $\begin{array}{l}1.05 \\
(0.94)\end{array}$ & $\begin{array}{l}-0.14 \\
(1.18)\end{array}$ & $\begin{array}{l}2.24^{* *} \\
(1.03)\end{array}$ & $\begin{array}{c}1.38 \\
(0.98)\end{array}$ & $\begin{array}{c}0.10 \\
(1.20)\end{array}$ & $\begin{array}{c}2.67^{* * *} \\
(0.96)\end{array}$ \\
\hline Quala-e-Noorak & $\begin{array}{c}0.09 \\
(0.76)\end{array}$ & $\begin{array}{c}0.23 \\
(1.17)\end{array}$ & $\begin{array}{l}-0.05 \\
(1.05)\end{array}$ & $\begin{array}{c}0.34 \\
(0.70)\end{array}$ & $\begin{array}{c}0.80 \\
(1.10)\end{array}$ & $\begin{array}{l}-0.12 \\
(0.94)\end{array}$ \\
\hline Shuran-e-Bala & $\begin{array}{l}-0.39 \\
(0.82)\end{array}$ & $\begin{array}{l}-0.34 \\
(1.42)\end{array}$ & $\begin{array}{l}-0.43 \\
(0.95)\end{array}$ & $\begin{array}{c}0.21 \\
(0.76)\end{array}$ & $\begin{array}{c}0.83 \\
(1.31)\end{array}$ & $\begin{array}{l}-0.40 \\
(0.85)\end{array}$ \\
\hline Kalahkan Pain & $\begin{array}{l}-0.41 \\
(0.81)\end{array}$ & $\begin{array}{l}-0.27 \\
(1.20)\end{array}$ & $\begin{array}{l}-0.55 \\
(1.18)\end{array}$ & $\begin{array}{l}-0.41 \\
(0.75)\end{array}$ & $\begin{array}{l}-0.32 \\
(1.20)\end{array}$ & $\begin{array}{l}-0.50 \\
(0.99)\end{array}$ \\
\hline Constant & $\begin{array}{c}3.29^{* * *} \\
(0.65)\end{array}$ & $\begin{array}{c}3.14^{* * *} \\
(1.06)\end{array}$ & $\begin{array}{c}3.43^{* * *} \\
(0.84)\end{array}$ & $\begin{array}{c}2.79^{* * *} \\
(0.62)\end{array}$ & $\begin{array}{c}2.57^{* *} \\
(1.05)\end{array}$ & $\begin{array}{c}3.00^{* * *} \\
(0.76)\end{array}$ \\
\hline Observations & 136 & 68 & 68 & 136 & 68 & 68 \\
\hline R-squared & 0.16 & 0.21 & 0.20 & 0.13 & 0.23 & 0.21 \\
\hline
\end{tabular}

Notes: OLS coefficients. The constant represents the omitted village, Kalakhan-e-Bala. Robust standard errors in parentheses. ${ }^{* * *}$ denotes significance at 1 percent level, ${ }^{* *}$ at 5 percent level and ${ }^{*}$ at 10 percent level. In Columns 1 to 3 the dependent variable is the dictator game (DG) transfer in ECUs (range from 0 to 10). In Columns 4 to 6 the dependent variable is the third party punishment game (TPPG) transfer in ECUs (range from 0 to $10)$. 


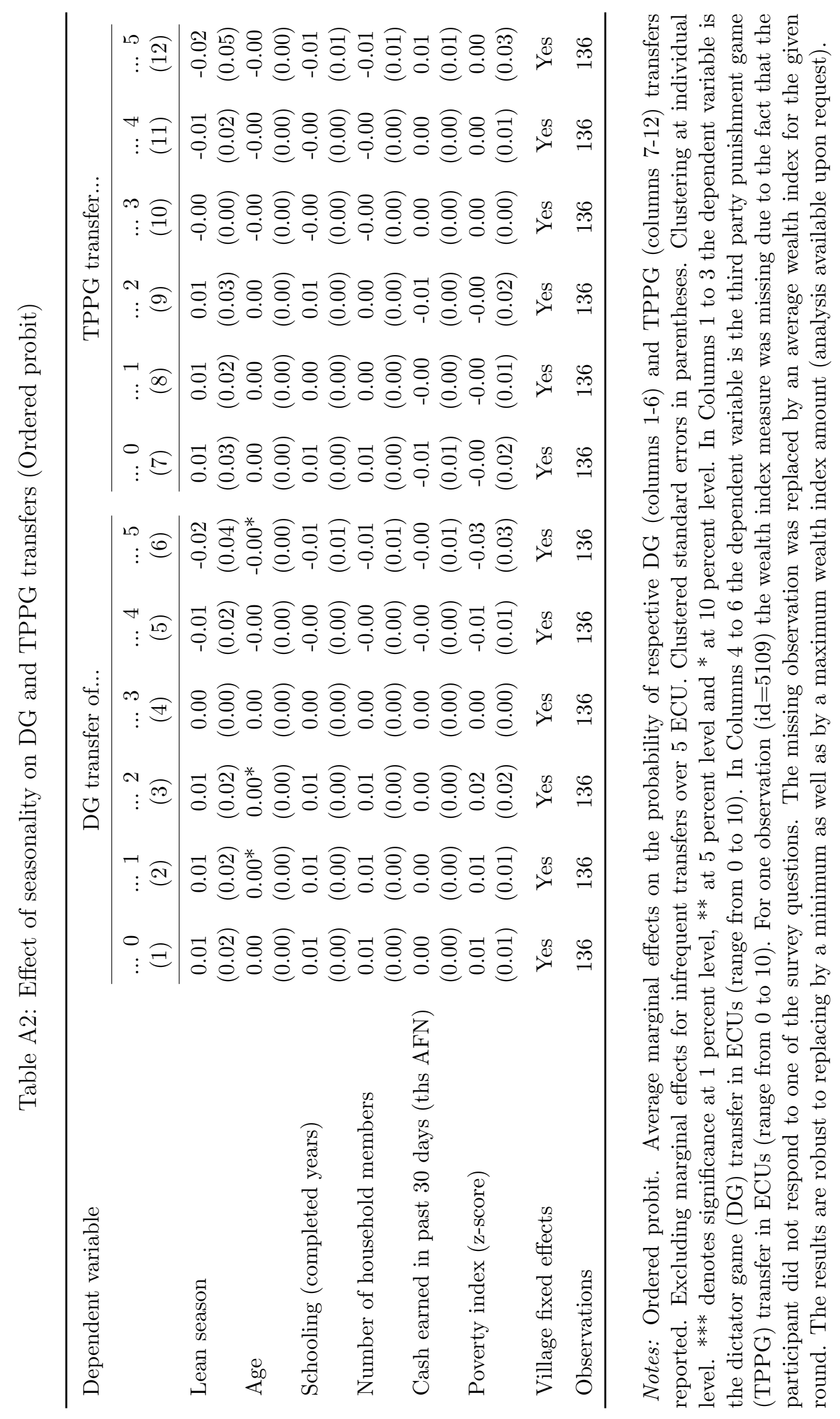


Table A3: Effect of seasonality on TPPG MAO (Ordered probit)

\begin{tabular}{lcccccc}
\hline \multirow{2}{*}{ Dependent variable } & \multicolumn{5}{c}{ TPPG Minimum Acceptable Offer of... } \\
\cline { 2 - 7 } & $\ldots 0$ & $\ldots 1$ & $\ldots 2$ & $\ldots 3$ & $\ldots 4$ & $\ldots 5$ \\
& $(1)$ & $(2)$ & $(3)$ & $(4)$ & $(5)$ & $(6)$ \\
\cline { 2 - 7 } Lean season & $0.27^{* * *}$ & $0.13^{* * *}$ & -0.01 & $-0.13^{* * *}$ & $-0.11^{* * *}$ & $-0.10^{* * *}$ \\
Age & $(0.07)$ & $(0.04)$ & $(0.02)$ & $(0.04)$ & $(0.03)$ & $(0.03)$ \\
& $0.01^{* *}$ & $0.00^{* *}$ & -0.00 & $-0.00^{* *}$ & $-0.00^{* *}$ & $-0.00^{*}$ \\
Schooling (completed years) & $(0.00)$ & $(0.00)$ & $(0.00)$ & $(0.00)$ & $(0.00)$ & $(0.00)$ \\
Number of household members & -0.00 & -0.00 & 0.00 & 0.00 & 0.00 & 0.00 \\
Cash earned in past 30 days (ths AFN) & $(0.01)$ & $(0.00)$ & $(0.00)$ & $(0.00)$ & $(0.00)$ & $(0.00)$ \\
& 0.01 & 0.00 & -0.00 & -0.00 & -0.00 & -0.00 \\
Poverty index (z-score) & $(0.01)$ & $(0.00)$ & $(0.00)$ & $(0.00)$ & $(0.00)$ & $(0.00)$ \\
& $(0.01)$ & $(0.01)$ & $(0.00)$ & $(0.01)$ & $(0.00)$ & $(0.00)$ \\
Village fixed effects & $0.05^{* *}$ & $0.03^{*}$ & -0.00 & $-0.03^{*}$ & $-0.02^{*}$ & $-0.02^{*}$ \\
Observations & $(0.03)$ & $(0.02)$ & $(0.00)$ & $(0.02)$ & $(0.01)$ & $(0.01)$ \\
\hline
\end{tabular}

Notes: Ordered probit. Average marginal effects on the probability of respective TPPG MAO reported. Excluding marginal effects for infrequent TPPG MAO over 5. Clustered standard errors in parentheses. Clustering at individual level. *** denotes significance at 1 percent level, ** at 5 percent level and * at 10 percent level. The dependent variable in all models is the third party punishment game (TPPG) minimum acceptable offer (MAO). Subsample of $\mathrm{N}=123$ observations (60 lean season, 63 post-harvest season) with consistent MAO. 


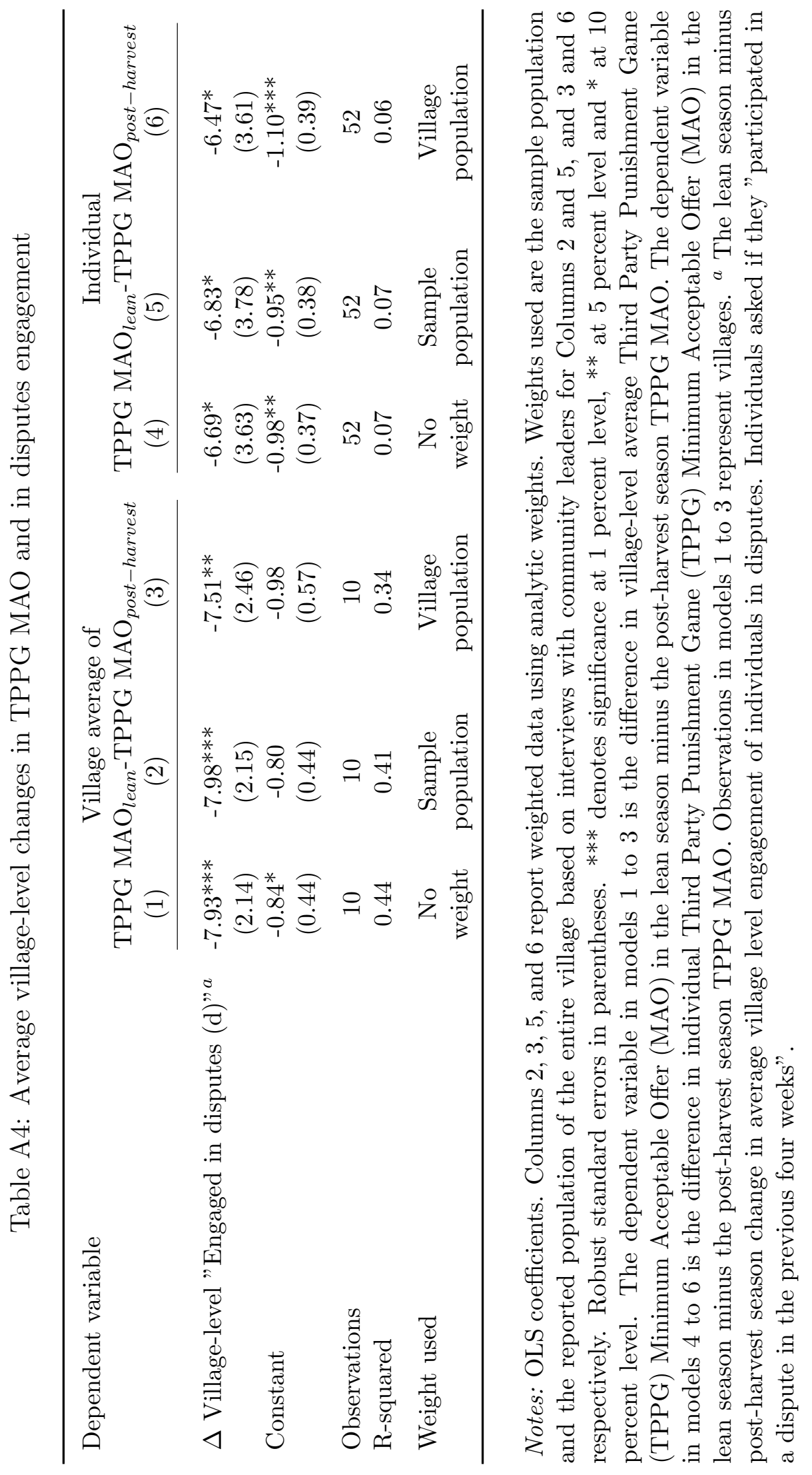




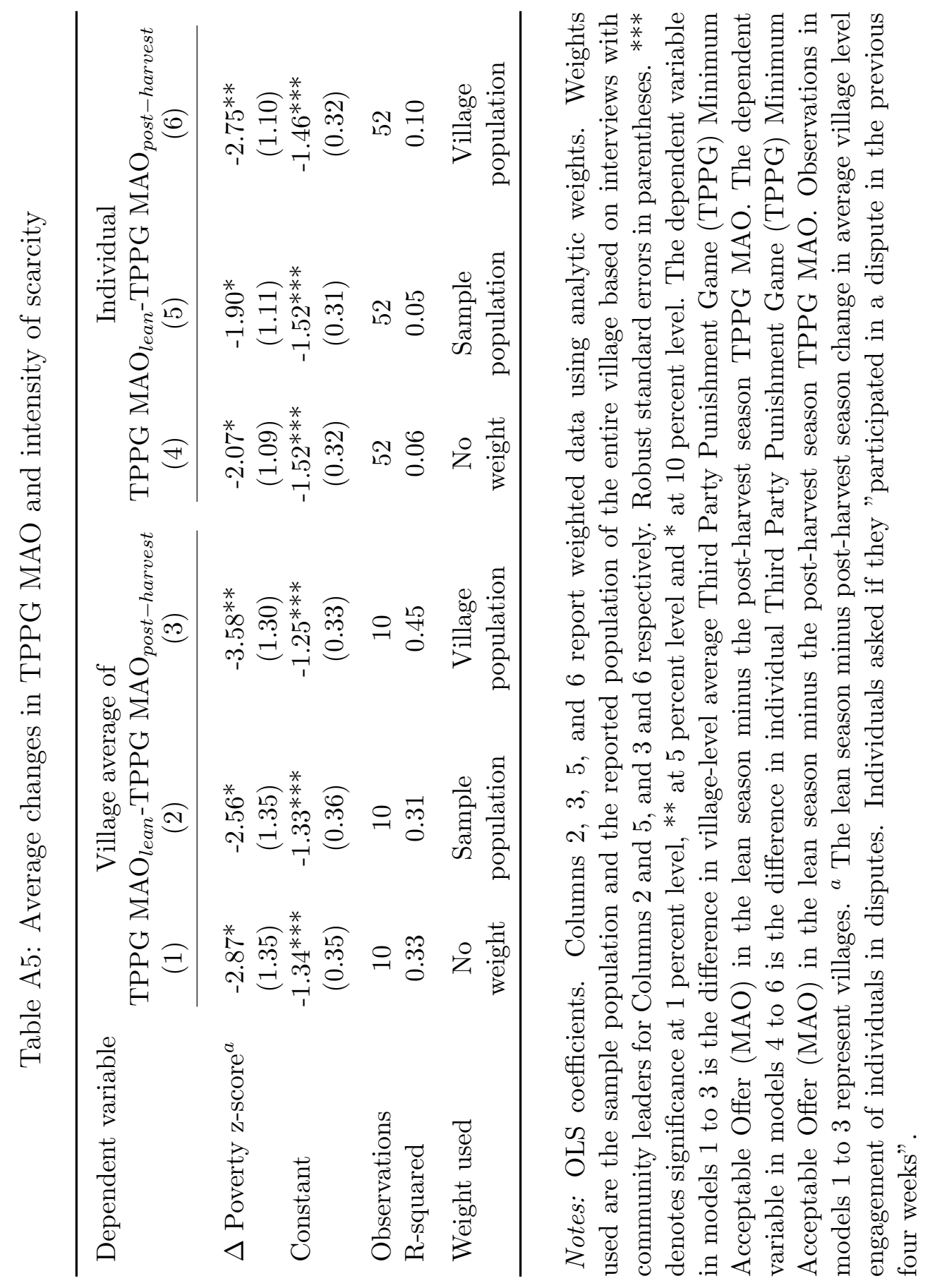


Table A6: Effect of seasonality on DG transfers, TPPG transfers, and TPPG MAO (by ethnic group)

\begin{tabular}{|c|c|c|c|c|c|c|}
\hline \multirow[t]{2}{*}{ Dependent variable } & \multicolumn{3}{|c|}{ Tajik } & \multicolumn{3}{|c|}{ Hazara } \\
\hline & $\begin{array}{c}\mathrm{DG} \\
\text { transfer } \\
(1)\end{array}$ & $\begin{array}{c}\text { TPPG } \\
\text { transfer } \\
(2)\end{array}$ & $\begin{array}{c}\text { TPPG } \\
\text { Minimum } \\
\text { Acceptable } \\
\text { Offer } \\
(3)\end{array}$ & $\begin{array}{c}\mathrm{DG} \\
\text { transfer } \\
(4)\end{array}$ & $\begin{array}{c}\text { TPPG } \\
\text { transfer } \\
(5)\end{array}$ & $\begin{array}{c}\text { TPPG } \\
\text { Minimum } \\
\text { Acceptable } \\
\text { Offer } \\
(6)\end{array}$ \\
\hline Lean season & $\begin{array}{l}-0.00 \\
(0.38)\end{array}$ & $\begin{array}{c}0.43 \\
(0.37)\end{array}$ & $\begin{array}{c}-2.09 * * * \\
(0.51)\end{array}$ & $\begin{array}{l}-0.21 \\
(0.41)\end{array}$ & $\begin{array}{l}-0.72 \\
(0.59)\end{array}$ & $\begin{array}{c}-1.23^{* *} \\
(0.50)\end{array}$ \\
\hline Age & $\begin{array}{l}-0.02 \\
(0.02)\end{array}$ & $\begin{array}{l}-0.01 \\
(0.02)\end{array}$ & $\begin{array}{c}-0.05^{* * *} \\
(0.02)\end{array}$ & $\begin{array}{c}-0.05^{* * *} \\
(0.02)\end{array}$ & $\begin{array}{c}-0.04^{* *} \\
(0.02)\end{array}$ & $\begin{array}{c}0.00 \\
(0.02)\end{array}$ \\
\hline Schooling (completed years) & $\begin{array}{l}-0.16^{*} \\
(0.08)\end{array}$ & $\begin{array}{l}-0.10 \\
(0.07)\end{array}$ & $\begin{array}{l}-0.03 \\
(0.05)\end{array}$ & $\begin{array}{c}0.04 \\
(0.07)\end{array}$ & $\begin{array}{l}-0.01 \\
(0.07)\end{array}$ & $\begin{array}{c}0.05 \\
(0.10)\end{array}$ \\
\hline Number of household members & $\begin{array}{l}-0.09 \\
(0.07)\end{array}$ & $\begin{array}{l}-0.08 \\
(0.06)\end{array}$ & $\begin{array}{l}-0.04 \\
(0.04)\end{array}$ & $\begin{array}{c}0.00 \\
(0.04)\end{array}$ & $\begin{array}{c}0.00 \\
(0.06)\end{array}$ & $\begin{array}{l}-0.07 \\
(0.09)\end{array}$ \\
\hline $\begin{array}{l}\text { Cash earned in past } \\
30 \text { days (ths AFN) }\end{array}$ & $\begin{array}{c}0.02 \\
(0.08)\end{array}$ & $\begin{array}{c}0.15^{* *} \\
(0.07)\end{array}$ & $\begin{array}{c}-0.31^{* * *} \\
(0.08)\end{array}$ & $\begin{array}{l}-0.05 \\
(0.05)\end{array}$ & $\begin{array}{c}0.00 \\
(0.06)\end{array}$ & $\begin{array}{l}-0.04 \\
(0.03)\end{array}$ \\
\hline Poverty index (z-score) & $\begin{array}{l}-0.15 \\
(0.23)\end{array}$ & $\begin{array}{l}-0.09 \\
(0.18)\end{array}$ & $\begin{array}{l}-0.20 \\
(0.22)\end{array}$ & $\begin{array}{l}-0.15 \\
(0.28)\end{array}$ & $\begin{array}{c}0.28 \\
(0.36)\end{array}$ & $\begin{array}{c}-0.41^{* *} \\
(0.16)\end{array}$ \\
\hline $\begin{array}{l}\text { Village fixed effects } \\
\text { Constant }\end{array}$ & $\begin{array}{c}\text { Yes } \\
5.53^{* * *} \\
(1.11)\end{array}$ & $\begin{array}{c}\text { Yes } \\
3.70^{* * *} \\
(0.94)\end{array}$ & $\begin{array}{c}\text { Yes } \\
6.71^{* * *} \\
(1.27)\end{array}$ & $\begin{array}{c}\text { Yes } \\
7.43^{* * *} \\
(0.88)\end{array}$ & $\begin{array}{c}\text { Yes } \\
6.99^{* * *} \\
(0.88)\end{array}$ & $\begin{array}{c}\text { Yes } \\
4.41^{* * *} \\
(0.95)\end{array}$ \\
\hline Observations & 72 & 72 & 63 & 64 & 64 & 60 \\
\hline R-squared & 0.24 & 0.23 & 0.52 & 0.42 & 0.27 & 0.30 \\
\hline
\end{tabular}

Notes: OLS coefficients. Clustered standard errors in parentheses. Clustering at individual level. *** denotes significance at 1 percent level, ${ }^{* *}$ at 5 percent level and ${ }^{*}$ at 10 percent level. In Columns 1 and 4 the dependent variable is the dictator game (DG) transfer in ECUs (range from 0 to 10). In Columns 2 to 5 the dependent variable is the third party punishment game (TPPG) transfer in ECUs (range from 0 to 10). In Columns 3 to 6 the dependent variable in all models is the third party punishment game (TPPG) minimum acceptable offer (MAO). 
Table A7: Effect of seasonality on DG and TPPG transfers (subsample of PAs who do not recall their own previous round DG transfer)

\begin{tabular}{|c|c|c|c|c|c|c|}
\hline \multirow[t]{2}{*}{ Dependent variable } & \multicolumn{3}{|c|}{ DG transfer } & \multicolumn{3}{|c|}{ TPPG transfer } \\
\hline & $(1)$ & $(2)$ & $(3)$ & $(4)$ & $(5)$ & $(6)$ \\
\hline Lean season & $\begin{array}{l}-0.13 \\
(0.29)\end{array}$ & $\begin{array}{l}-0.13 \\
(0.31)\end{array}$ & $\begin{array}{l}-0.04 \\
(0.40)\end{array}$ & $\begin{array}{l}-0.15 \\
(0.35)\end{array}$ & $\begin{array}{l}-0.15 \\
(0.37)\end{array}$ & $\begin{array}{c}-0.05 \\
(0.48)\end{array}$ \\
\hline Age & & & $\begin{array}{l}-0.03 \\
(0.02)\end{array}$ & & & $\begin{array}{l}-0.02 \\
(0.01)\end{array}$ \\
\hline Schooling (completed years) & & & $\begin{array}{l}-0.10 \\
(0.08)\end{array}$ & & & $\begin{array}{c}-0.09 \\
(0.06)\end{array}$ \\
\hline Number of household members & & & $\begin{array}{l}-0.08 \\
(0.07)\end{array}$ & & & $\begin{array}{l}-0.05 \\
(0.07)\end{array}$ \\
\hline Cash earned in past 30 days (ths AFN) & & & $\begin{array}{l}-0.08 \\
(0.06)\end{array}$ & & & $\begin{array}{c}0.02 \\
(0.07)\end{array}$ \\
\hline Poverty index (z-score) & & & $\begin{array}{l}-0.23 \\
(0.20)\end{array}$ & & & $\begin{array}{l}-0.07 \\
(0.20)\end{array}$ \\
\hline $\begin{array}{l}\text { Village fixed effects } \\
\text { Constant }\end{array}$ & $\begin{array}{c}\text { No } \\
3.28^{* * *} \\
(0.28)\end{array}$ & $\begin{array}{c}\text { Yes } \\
3.87^{* * *} \\
(1.13)\end{array}$ & $\begin{array}{c}\text { Yes } \\
5.96^{* * *} \\
(1.40)\end{array}$ & $\begin{array}{c}\text { No } \\
3.15^{* * *} \\
(0.26)\end{array}$ & $\begin{array}{c}\text { Yes } \\
3.48^{* * *} \\
(0.82)\end{array}$ & $\begin{array}{c}\text { Yes } \\
4.93^{* * *} \\
(1.22)\end{array}$ \\
\hline Observations & 92 & 92 & 92 & 92 & 92 & 92 \\
\hline R-squared & 0.00 & 0.18 & 0.28 & 0.00 & 0.12 & 0.18 \\
\hline
\end{tabular}

Notes: OLS coefficients. Clustered standard errors in parentheses. Clustering at individual level. *** denotes significance at 1 percent level, ${ }^{* *}$ at 5 percent level and ${ }^{*}$ at 10 percent level. In Columns 1 to 3 the dependent variable is the dictator game (DG) transfer in ECUs (range from 0 to 10). In Columns 4 to 6 the dependent variable is the third party punishment game (TPPG) transfer in ECUs (range from 0 to 10). Subsample of 46 PAs who did not recall their DG transfers from the previous, lean season round. 


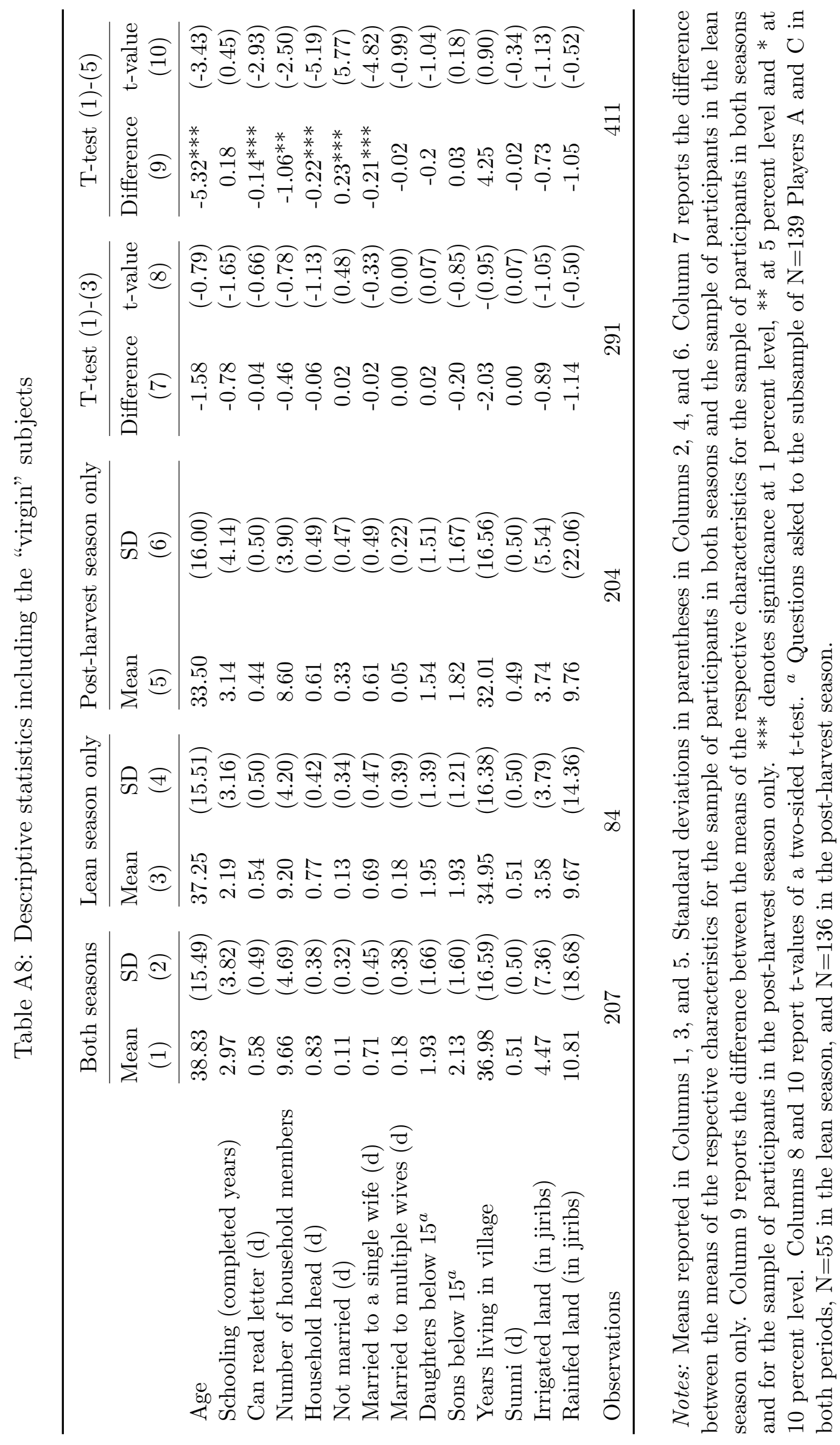


Table A9: Differences TPPG MAO by subjects participating in both rounds and in one round only

\begin{tabular}{|c|c|c|c|}
\hline Dependent variable & $\begin{array}{l}\text { TPPG } \\
\text { (1) }\end{array}$ & $\begin{array}{l}\text { Cinimum } \\
\qquad(2)\end{array}$ & $\begin{array}{c}\text { Acceptable Offer } \\
(3)\end{array}$ \\
\hline Lean season ("virgin") & $\begin{array}{c}1.87^{* * * *} \\
(0.35)\end{array}$ & $\begin{array}{c}1.75^{* * *} \\
(0.51)\end{array}$ & $\begin{array}{c}2.45^{* * * *} \\
(0.78)\end{array}$ \\
\hline Lean season (both seasons) & $\begin{array}{c}1.35^{* * *} \\
(0.19)\end{array}$ & $\begin{array}{c}1.44^{* * *} \\
(0.38)\end{array}$ & $\begin{array}{c}2.10^{* * *} \\
(0.66)\end{array}$ \\
\hline Post-harvest season (both seasons) & $\begin{array}{c}3.03^{* * *} \\
(0.24)\end{array}$ & $\begin{array}{c}3.08^{* * *} \\
(0.43)\end{array}$ & $\begin{array}{c}3.44^{* * *} \\
(0.68)\end{array}$ \\
\hline Post-harvest season ("virgin") & $\begin{array}{c}3.39 * * * \\
(0.28)\end{array}$ & $\begin{array}{c}3.33^{* * *} \\
(0.41)\end{array}$ & $\begin{array}{c}3.71^{* * *} \\
(0.61)\end{array}$ \\
\hline Age & & & $\begin{array}{l}-0.01 \\
(0.01)\end{array}$ \\
\hline Schooling (completed years) & & & $\begin{array}{c}0.04 \\
(0.04)\end{array}$ \\
\hline Number of household members & & & $\begin{array}{l}-0.03 \\
(0.03)\end{array}$ \\
\hline Cash earned in past 30 days (ths AFN) & & & $\begin{array}{l}-0.05 \\
(0.03)\end{array}$ \\
\hline Poverty index (z-score) & & & $\begin{array}{c}-0.35^{* * *} \\
(0.13)\end{array}$ \\
\hline Village fixed effects & No & Yes & Yes \\
\hline Observations & 203 & 203 & 200 \\
\hline R-squared & 0.68 & 0.71 & 0.73 \\
\hline
\end{tabular}

Notes: OLS coefficients. Regression without a constant. Robust standard errors in parentheses. ${ }^{* * *}$ denotes significance at 1 percent level, $* *$ at 5 percent level and $*$ at 10 percent level. The dependent variable in all models is the third party punishment game (TPPG) minimum acceptable offer (MAO). Subsample of $\mathrm{N}=200$ observations (23 lean season "virgin", 60 lean season participating in both seasons, 63 post-harvest season participating in both seasons, and 57 post-harvest season "virgin") with consistent MAO. 


\section{B Image documentation}

Figure A1: Selection of experimental subjects from interested villagers

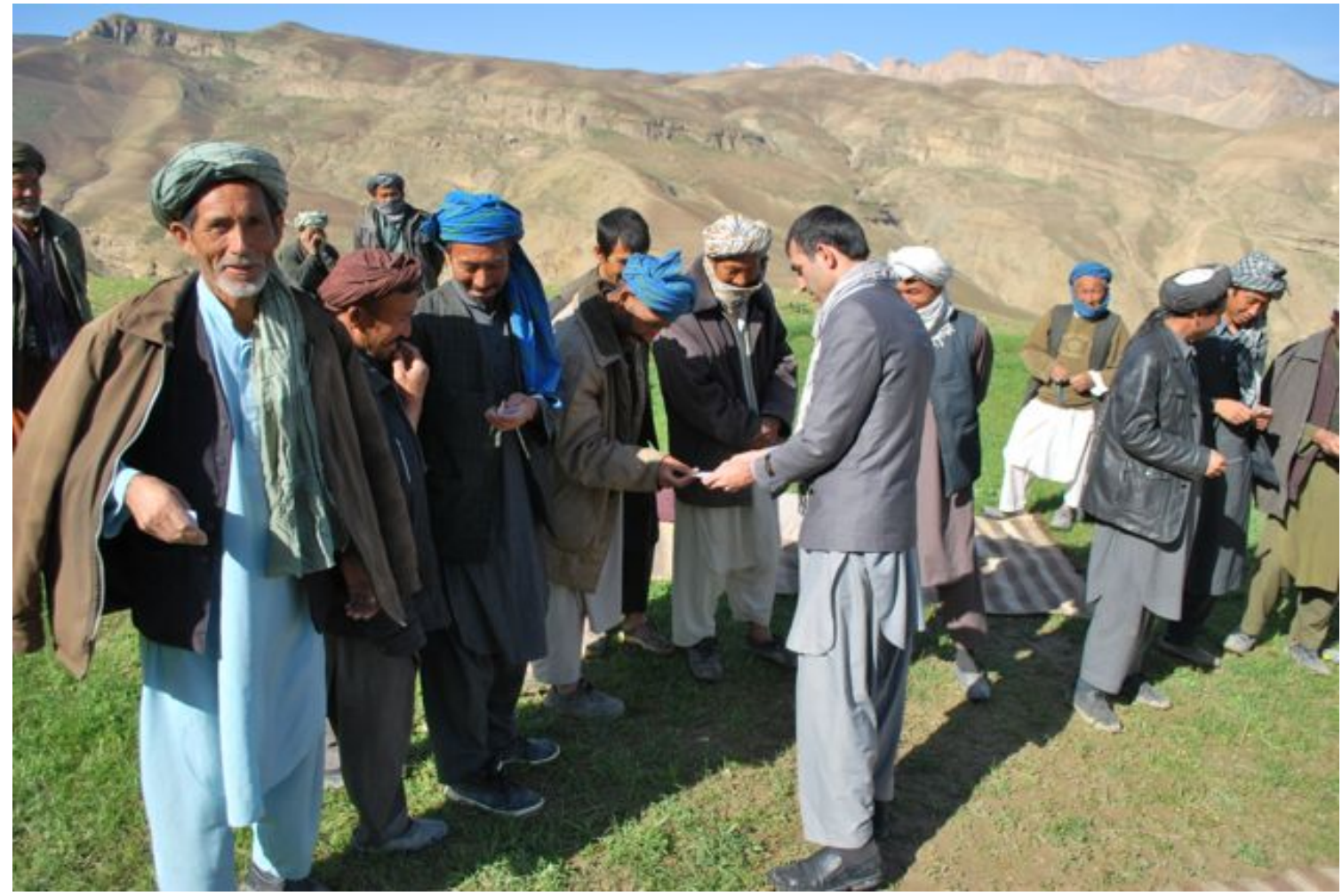

Figure A2: Explaining instructions in a group

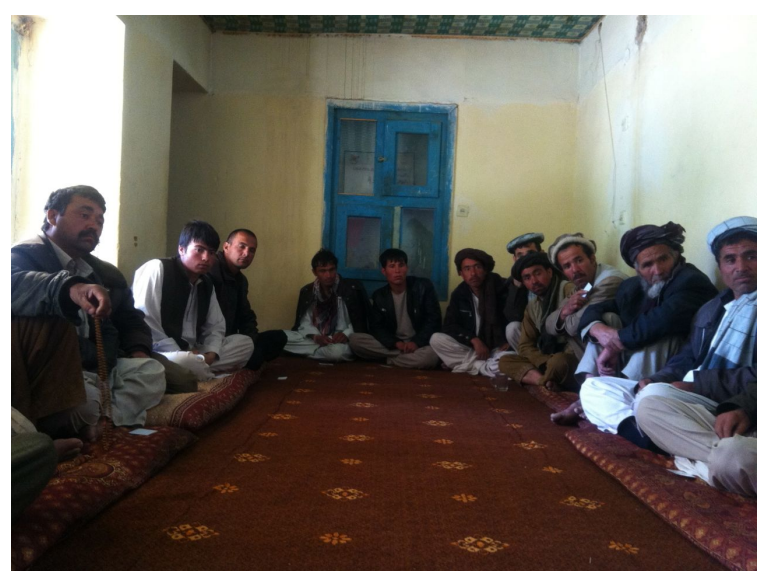

(a) Experimental subjects

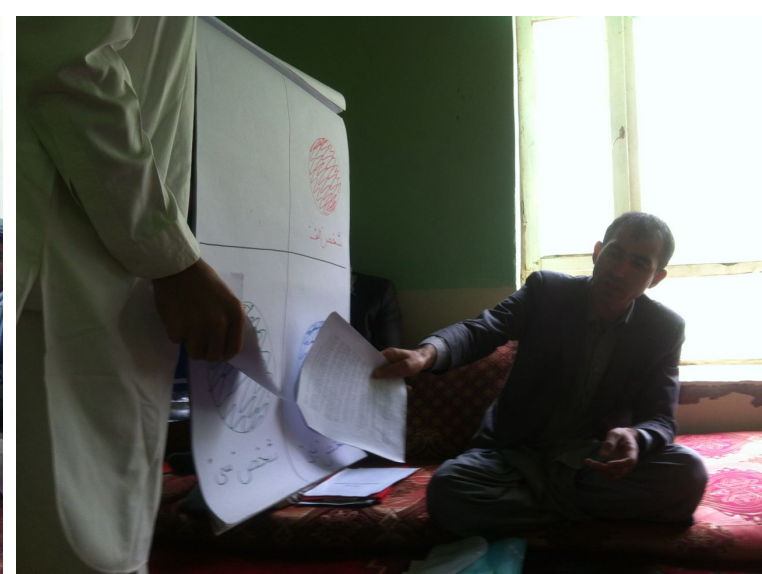

(b) Explaining instructions in a group 
Figure A3: Individual player experimental sessions

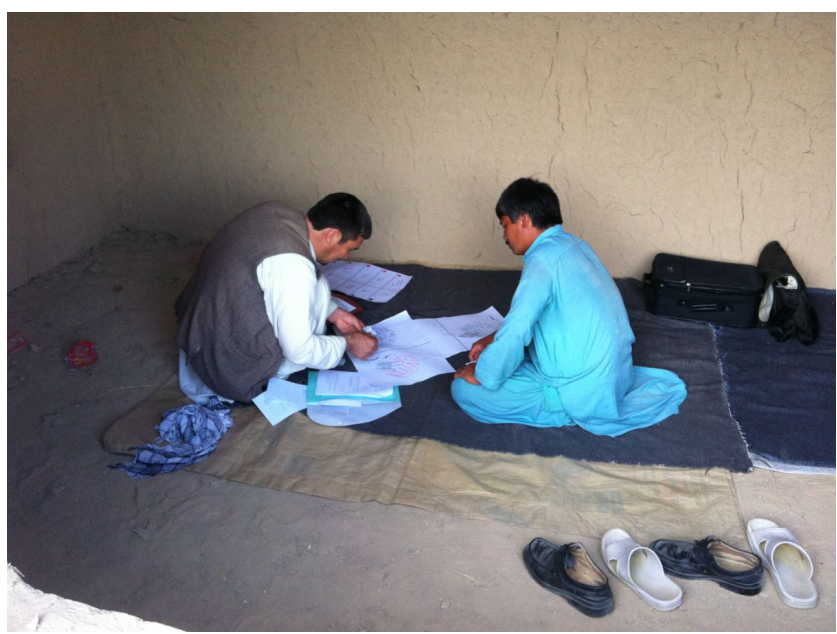

(a) Individual session 1

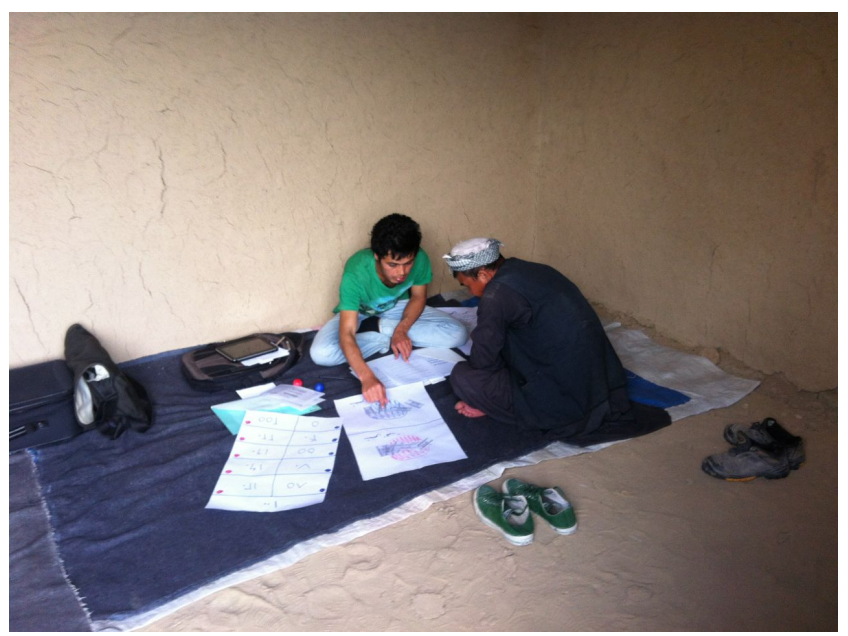

(b) Individual session 2

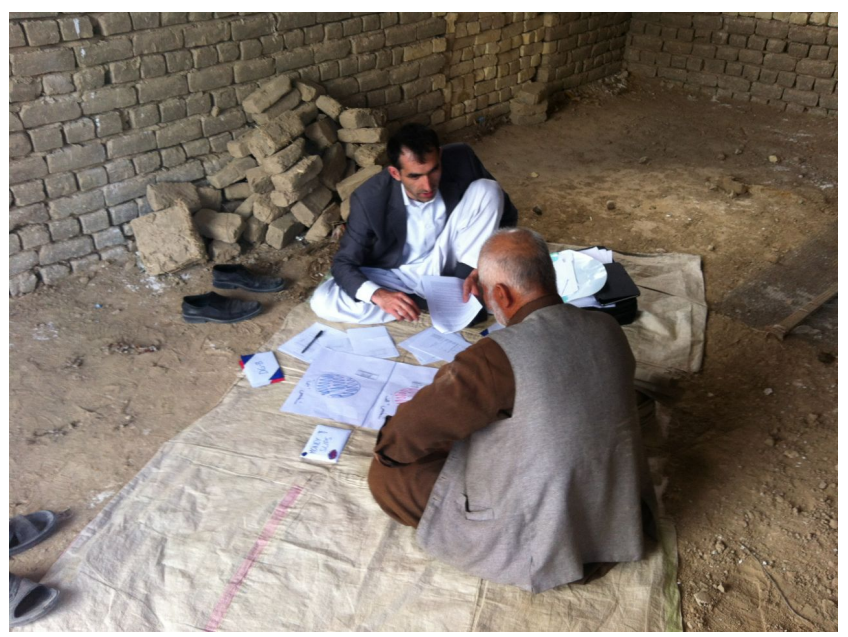

(c) Individual session 3 


\section{Experimental script}

\section{C.1 Group general instructions}

Before we begin I want to tell you about what we are doing here today and explain the rules that we must follow. We will be making a task in which you can get some money. Whatever money you will get in the task will be yours to keep and take home.

Maybe you won't get any money from the task, but if you decide to stay with us today, I will pass out $100 \mathrm{AFN}$ to each of you to thank you for coming today. This money is not part of the task, it will be yours to keep. You will also get some snack and tea when you finish the task.

You should understand that this is not our own money. A University gave this money to us for research. This payment will not be regularly repeated in the future. It is not assistance, you will get the money for the task you will do here for us. It is not even a survey that you may have experienced before.

Please, also understand that there is no relation between our University and the organization People in Need delivering assistance in this area for a long period. I will not tell the organization about what you did here. Also, nothing you do here today will affect how the organization treats you or your community.

You should understand that there are no "right" or "wrong" answers in this task. Also, let me stress something that is very important. You were invited here without understanding what we are planning to do today. If you find that this is something that you do not wish to participate in, you can leave anytime.

Now, I will explain the task to you in the group. Later one after the other will come with me to carry out the task. It is important that you listen as carefully as possible, because only people who understand the task will actually be invited to participate. We will run through some examples here while we are all together.

You cannot ask questions or talk while we are here in the group. This is very important. Please be sure that you obey this rule, because it is possible for one person to spoil the task for everyone. If one person talks about the task while sitting in the group, we will not be able to carry out the task today. But do not worry if you do not completely understand the task as I show you the examples here in the group. Each of you will have time to ask questions when we sit alone together to be sure that you understand what you have to do. Now I will explain you what we are going to do during the task.

\section{C.2 Group games instructions: Dictator game}

In one part of the task there will be two persons - Person A, and Person B. Both persons come from this village. None of you will know exactly with whom you are interacting. Only I know who will interact with whom and I will never tell anyone else.

Here are 200 AFN in 20 AFN bills that I will give to a Person A. Person A must decide how much of these 200 AFN he wants to give to Person B and how much he wants to keep for himself. I will not give any money to Person B. Person B takes home whatever Person A gives to him. 
Here are some examples:

1. Suppose Person A gives 100 AFN to Person B, and keeps 100 AFN for himself. Person A goes home with 100 AFN (From the 200 AFN he had given 100 AFN to Person B and had kept 100 AFN for himself). Person B goes home with the 100 AFN from Person A.

2. Here is another example. Suppose Person A gives 0 AFN to Person B and keeps 200 AFN for himself. In this case, Person A goes home with 200 AFN. Person B doesn't have anything.

3. Here is another example. Suppose Person A gives 200 AFN to Person B and keeps 0 AFN for himself. In this case, Person A goes home with 0 AFN. Person B goes home with the 200 AFN from Person A.

4. Here is another example. This time suppose Person A gives 60 AFN to Person B and keeps 140 AFN for himself. In this case, Person A goes home with 140 AFN. Person B goes home with the 60 AFN from Person A.

Note again, there are no "right" or "wrong" answers in this task.

\section{C.3 Group games instructions: Third party punishment game}

In another part of the task, there will be three persons - Person A, Person B, and Person C. All three persons come from this village. None of you will know exactly with whom you are interacting, but it will definitely not be the person with which you interacted in the previous part of the task. Only I know who will interact with whom and I will never tell anyone else.

Here is another 200 AFN. Person A must decide how much of these 200 AFN he wants to give to Person B and how much he wants to keep for himself. Person B takes home whatever Person A gives to him, but Person A has to wait until Person $\mathrm{C}$ has made a decision before finding out what he is going to take home. Person $\mathrm{C}$ is given $100 \mathrm{AFN}$. Person C can make three things with his 100 AFN.

1. He can pay 20 AFN to subtract 60 AFN of Person A's money, which Person A wanted to keep for himself. This money will be taken away; none of the Persons will get it. Person $\mathrm{C}$ will keep the remaining $80 \mathrm{AFN}$.

2. He can pay 40 AFN to subtract 120 AFN of Person A's money, which Person A wanted to keep for himself. This money will be taken away; none of the Persons will get it. Person $\mathrm{C}$ will keep the remaining 60 AFN.

3. He can pay nothing, keep all of the 100 AFN for himself and leave the money Person A wanted to keep for himself untouched.

Before hearing how much Person A has given to Person B, Person $\mathrm{C}$ has to decide what he wants to do for each of the possible amounts that Person A can give to Person B. This is 0 AFN, 20 AFN, 40 AFN, 60 AFN, 80 AFN, 100 AFN, 120 AFN, 140 AFN, 160 AFN, 180 AFN, or 200 AFN. 
Here are some examples (All examples are shown with 20 AFN banknotes):

1. Here is another example. Suppose Person A gives 200 AFN to Person B and keeps 0 AFN for himself. Person C states that he would "do nothing" if Person A does this. In this case, Person A goes home with 0 AFN. Person B goes home with the 200 AFN from Person A, and Person C goes home with 100 AFN.

2. Here is another example. Suppose Person A gives 60 AFN to Person B and keeps 140 AFN for himself. Person C states that he would "do nothing" if Person A does this. In this case, Person A goes home with 140 AFN (He had kept 140 AFN for himself and Person C didn't decide to subtract money from him). Person B goes home with the 60 AFN from Person A. And Person C goes home with 100 AFN.

3. Here is another example. As before, Person A gives 60 AFN to Person B and keeps 140 AFN for himself. But now, Person C states that he would pay 20 AFN to subtract 60 AFN from Person A's money. In this case, Person A goes home with 80 AFN (He had kept 140 AFN for himself minus the 60 AFN equals 80 AFN). Person B goes home with the 60 AFN from Person A. And Person C goes home with 80 AFN.

4. And a last example: Suppose Person A gives 120 AFN to Person B and keeps 80 AFN for himself. Person $\mathrm{C}$ states that he would pay 20 AFN to subtract 60 AFN from Person A's money. In this case, Person A goes home with 20 AFN (He had kept 80 AFN for himself minus the 60 AFN equals 20 AFN). Person B goes home with the 120 AFN from Person A. And Person C goes home with 80 AFN (100 AFN minus 20 AFN equals 80 AFN).

Again, there are no "right" or "wrong" answers in this task.

We will then call each of you in turn to make the task, starting with the person who picked number 1 . In case you cannot read numbers, we will assist you.

When you finish the task, you have to wait until everybody has finished. Then I will call you in one by one again and I will tell you whether you have gained something. If yes, I will pay you that amount plus you will get the 100 AFN I promised you at the beginning.

We will not pay you for both tasks. At the end of the session you will have to pick a ball from a pouch to decide for which of the tasks you will get the payment. We will then give you the payment according to what color of the ball you picked. Please, take both tasks as if there was no other task before or after. Do you understand this?

Remember that you are not allowed to talk to the people still waiting to carry out the task. If you do talk to other people, the Assistant 3 will tell you to leave and not come back even if you may have earned some money. 


\begin{abstract}
Abstrakt
Sdílení zdrojů je jedním z mála způsobů, jakým se lidé $\mathrm{v}$ chudých komunitách zajišt'ují. Nejvýznamnějším se stává během negativních šoků, většinou agregátních, kdy je však sdílení pro jednotlivce nejnákladnější. Zatím se ví jen málo o tom, jak nedostatek ovlivňuje individuální ochotu sdílet a ochotu vynucovat sdílení od ostatních, což je zásadní ingrediencí pro zachování prosociálního chování. Tento článek se věnuje právě tématu sdílení na základě lab-in-the-field experimentů, kterých se účastnili farmáři v chudých venkovských oblastech severního Afghánistánu. Do experimentů se zapojili opakovaně - v období hladu (jež zažívají každoročně) a v období relativního dostatku po sklizni. Pomocí „hry na diktátora“ (dictator game) a hry $\mathrm{s}$ „,nestranným trestajícím“ (third-party punishment) je $\mathrm{v}$ experimentech rozlišována individuální ochota sdílet od ochoty vynucovat sdílení od ostatních. Zatímco sdílení vykazuje značnou míru stability v čase jak na agregátní, tak na individuální úrovni, vynucování sdílení je v období hladu značně oslabené. Toto zjištění ukazuje, že inkriminovaní farmáři jsou schopni udržovat vzájemné sdílení po dobu přechodných období nedostatku. Zůstává však otázkou, zda u komunit, jež jsou vystaveny nečekaným šokům či déle trvajícím obdobím nedostatku, může dojít kvůli oslabenému vynucování norem sdílení k rozpadu prosociálního chování.
\end{abstract}




\section{Working Paper Series}

ISSN 1211-3298

Registration No. (Ministry of Culture): E 19443

Individual researchers, as well as the on-line and printed versions of the CERGE-EI Working Papers (including their dissemination) were supported from institutional support RVO 67985998 from Economics Institute of the ASCR, v. v. i.

Specific research support and/or other grants the researchers/publications benefited from are acknowledged at the beginning of the Paper.

(c) Vojtěch Bartoš, 2016

All rights reserved. No part of this publication may be reproduced, stored in a retrieval system or transmitted in any form or by any means, electronic, mechanical or photocopying, recording, or otherwise without the prior permission of the publisher.

Published by

Charles University in Prague, Center for Economic Research and Graduate Education (CERGE) and

Economics Institute of the CAS, v. v. i. (EI)

CERGE-El, Politických vězňů 7, 11121 Prague 1, tel.: +420 224005 153, Czech Republic.

Printed by CERGE-EI, Prague

Subscription: CERGE-EI homepage: http://www.cerge-ei.cz

Phone: + 420224005153

Email: office@cerge-ei.cz

Web: http://www.cerge-ei.cz

Editor: Jan Zápal

The paper is available online at http://www.cerge-ei.cz/publications/working_papers/.

ISBN 978-80-7343-364-2 (Univerzita Karlova v Praze, Centrum pro ekonomický výzkum a doktorské studium)

ISBN 978-80-7344-368-9 (Národohospodářský ústav AV ČR, v. v. i.) 
CERGE-EI

P.O.BOX 882

Politických vězňů 7

11121 Praha 1

Czech Republic http://www.cerge-ei.cz 